\title{
A flow cytometric method to measure prokaryotic records in ice cores: an example from the West Antarctic Ice Sheet Divide drilling site
}

\author{
PAMELA A. SANTIBÁÑEZ, ${ }^{1}$ JOSEPH R. MCCONNELL, ${ }^{2}$ JOHN C. PRISCU ${ }^{1}$ \\ ${ }^{1}$ Department of Land Resources and Environmental Sciences, Montana State University, Bozeman, MT 59717, USA \\ ${ }^{2}$ Desert Research Institute, Nevada System of Higher Education, Reno, NV 8512, USA \\ Correspondence: Pamela A. Santibáñez <p.santibanez.avila@gmail.com>
}

\begin{abstract}
Microorganisms were the earliest inhabitants on our planet that occupy nearly every environment, and play a major role in biogeochemical cycles. Despite their global importance, there remains a paucity of data on microbial responses to long-term environmental and climatic changes. Microorganisms are known to be immured in glacial ice, but no high-resolution temporal records of their density exist, owing in large part to the lack of appropriate clean methodology that allows for rapid analysis of samples over depth. We describe a clean and time efficient method that can produce a high-temporal resolution record of prokaryotic density archived in ice cores. The method combines acquisition of discrete samples using a continuous ice-core melting system coupled with flow cytometry (FCM) of DNA-stained samples. Specifically, we evaluate the performance of the FCM measurement technique in terms of specificity, precision, accuracy and minimum detection limits. Examples from the West Antarctic Ice Sheet Divide ice core are included to show the efficacy of the method.
\end{abstract}

KEYWORDS: ice biology, ice core, microbiology, paleoclimate, prokaryotes

\section{INTRODUCTION}

Prokaryotes, which include the Bacterial and Archaeal domains, are the predominant organisms on Earth in terms of numbers and biomass (Whitman and others, 1998). They are also the most physiologically diverse and structurally simple group of organisms (e.g. Meyer, 1993; White, 2007), appearing on Earth 3.5 Ga BP (Rasmussen, 2000; Noffke and others, 2006; Javaux and others, 2010). Prokaryotes are drivers of key ecosystem functions such as nutrient cycling, degradation and mineralization of organic carbon and the regulation of global gas levels, all of which play an important role in the climate system (Finlay and others, 1997; Field, 1998; de Groot and others, 2002; Falkowski and others, 2008; Madsen, 2011). They have driven important changes in atmospheric composition such as the Great Oxidation Event ( 2.45 Ga), a consequence of the evolution of oxygenic photosynthesis (Kasting and Siefert, 2002; Kopp and others, 2005; Kump, 2008).

Despite the critical role of microorganisms during the evolution of the Earth system, they are not explicitly part of predictive climate models (Schimel, 2001; Singh and others, 2010). Their absence in climate models is the result of an incomplete understanding of microbial community responses to long-term climatic and environmental processes and therefore, their potential to influence climatic feedbacks (Schimel, 2001; Singh and others, 2010). Experimental and observational studies have indicated that microbial communities (abundance, composition and diversity) can significantly respond to and impact ecosystem-level processes at short-time scales (Castro and others, 2010; Yergeau and others, 2012; Singh and others, 2014; Park and others, 2015). In contrast, long-term perspectives obtained from paleorecords can present historical views old enough for a range of climate and ecosystem variability to occur (Gorham and others, 2001; Jackson and Erwin, 2006; Willis and Birks, 2006; Willis and others, 2010). An important archive of past climatic events is preserved in ice sheets. Although climatic and environmental changes have been well recorded and reconstructed from physical, chemical and isotopic records from polar ice cores (e.g., Dansgaard and others, 1993; Lüthi and others, 2008; Wolff and others, 2010), no comprehensive prokaryotic record from ice cores exists owing to a lack of clean and time efficient methods to measure these microorganisms.

Total prokaryotic cell concentrations have been shown to be present in the atmosphere at levels ranging between $10^{3}$ and $10^{9}$ cells m$^{-3}$ (e.g., Griffin and others, 2003; Griffin, 2007; Burrows and others, 2009a, b; Perfumo and Marchant, 2010; Hara and Zhang, 2012). These cells can be incorporated in glacial ice through dry and wet deposition at the surface of the ice. After deposition, the microorganisms are encased and incorporated into glacier ice (Barrie, 1985; Davidson and others, 1996; Priscu and others, 2007; Xiang and others, 2009). There, they can persist over extended periods of time due to the deeply frozen conditions within the Antarctic ice sheet (Priscu and Christner, 2004). Prokaryotes have been identified, cultured and quantified from discrete ice-core samples using both culture-dependent (e.g. Abyzov and others, 1998; Christner and others, 2000; Miteva and others, 2004) and culture-independent methods (e.g. Sheridan and others, 2003; Priscu and others, 2007; Miteva and others, 2009). To date, studies of prokaryotes have been limited to selected sections of ice cores and lack the high-temporal resolution to record their history through various climate scenarios.

Here, we describe a protocol using an ice-core melting system in combination with flow cytometry (FCM) of DNA- 
stained cells. To demonstrate its potential as a method to resolve non-photosynthetic prokaryotic concentrations in paleoclimatic studies of ice cores, we applied this method to a section of the West Antarctic Ice Sheet (WAIS) Divide (WD) ice core $(2100-2480 \mathrm{~m})$. We show that the use of FCM with a specific DNA stain allows the accurate and precise measurement of prokaryotic concentrations in ice cores, providing a millennial prokaryotic record.

\section{MATERIALS AND METHODS}

\subsection{Samples}

\subsubsection{Core samples}

Two sets of ice-core samples collected from the WD site were used in this study. The first sample set represents core sections 74, 85, 94 and $105 \mathrm{~m}$ below the surface collected in December 2005 (WDC05Q core; Banta and others, 2008). Following decontamination according to Christner and others (2005), the samples were melted at $4{ }^{\circ} \mathrm{C}$ and combined to obtain a total melt volume of $280 \mathrm{~mL}$. The second set corresponds to discrete meltwater samples from the deep WD ice core (WDC06A) retrieved between 2009 and 2011. Discrete liquid samples $(1-8 \mathrm{~mL})$ were obtained using a continuous ice-core melting system at the Desert Research Institute (McConnell and others, 2002). The depth range for the WDC06A analyzed section was $2100-2480 \mathrm{~m}$. These melted samples have a depth resolution from 25.4 to $98.7 \mathrm{~cm}(2.12-33.0 \mathrm{a})$ with a depth resolution average of $65.5 \mathrm{~cm}$, resulting in a mean time resolution of $12.1 \mathrm{a}$.

\subsubsection{Bacterial cultures}

Two Antarctic bacterial isolates from the Cotton Glacier (Dieser and others, 2010) and Lake Vostok accretion ice (Priscu and others, 1999; Christner and others, 2006) were used as test organisms during method development. The cultures were grown in $500 \mathrm{~mL}$ bottles and continuously shaken at $150 \mathrm{rpm}$ in a $7^{\circ} \mathrm{C}$ temperature-controlled incubator. They were fixed with $0.2 \mu \mathrm{m}$ filtered formalin ( $2 \%$ final concentration) once stationary phase growth was reached. The fixed bacterial cultures were immediately concentrated by centrifugation at $4600 \mathrm{~g}$ for $10 \mathrm{~min}$ in a $50 \mathrm{~mL}$ centrifuge tube at $10^{\circ} \mathrm{C}$ and washed four times with Milli-Q water. The cultures were re-suspended in Milli-Q water to $600 \mathrm{~mL}$ at a concentration of $10^{7}$ cells $\mathrm{mL}^{-1}$ and stored at $4^{\circ} \mathrm{C}$ until use.

\subsubsection{Glacier sediments}

Heat-sterilized control sediments from Robertson Glacier (Canada) were combusted at $450^{\circ} \mathrm{C}$ for $3 \mathrm{~h}$ to eliminate organic matter. The sediments, composed primarily of calcite, dolomite, quartz, k-feldspar and muscovite, were then screen fractionated into $<63$ and $63-125 \mu \mathrm{m}$ size classes for experimental use. Following this treatment, sediments were mixed in varying configurations with the bacterial cultures to assess the degree to which they interfere with the flow cytometric assay.

\subsection{Ice-core melter}

The well-established ice-core analytical system located at Desert Research Institute includes an array of mass spectrometers, fluorometers, spectrophotometers and other instruments for continuous determination of $\sim 35$ elements, chemical species, and isotopes (adapted from McConnell and others, 2002). The melting system resides in a $-20^{\circ} \mathrm{C}$ clean cold room, with many measurements conducted in near-real-time in an adjacent class-100 clean room (ISO 5). To avoid contamination from the external part of the core, the samples for microbiological characterization were taken from the $1.3 \mathrm{~cm} \times 1.3 \mathrm{~cm}$ center ring (total area $=1.69 \mathrm{~cm}^{2}$ ) of the three-ring melter plate. This region represents the inner-most $\sim 10 \%$ of the sample cross section. The meltwater from the inner ring was pumped from the melter head through polytetrafluoroethylene (PTFE) tubing $(0.76 \mathrm{~mm}$ i.d.). The meltwater was captured in $8 \mathrm{~mL}$ amber borosilicate glass vials with PTFE liner caps previously acid-washed $(10 \% \mathrm{HCl})$ and combusted $\left(450^{\circ} \mathrm{C}\right.$ for $\left.4 \mathrm{~h}\right)$. The sample collection system was automated using a Gilson temperature controlled $\left(4^{\circ} \mathrm{C}\right)$ fraction collector so that known volumes of sample were dispensed into the vials using a large needle to penetrate the septa at a melting rate of $\sim 4 \mathrm{~cm} \mathrm{~min}^{-1}$, (i.e. the vials were never opened once combusted). To minimize potential contamination, deionized water (after two stages of cleaning: reverse osmosis and deionization using mixedbed resin filters, further cleaned in the ice-core laboratory using an Elga Pure Laboratory Ultra polishing unit) was used routinely to rinse and irrigate the melter head between ice sections. The discrete melted glacial samples were fixed with $0.2 \mu \mathrm{m}$ filtered formalin ( $2 \%$ final concentration) and stored at $4{ }^{\circ} \mathrm{C}$ until analysis. Additional longitudinal ice sections from the same core taken from parallel depths were used to repeat measurements. The replicate sections were melted between 1 and $60 \mathrm{~d}$ after the original sections, to demonstrate the reproducibility of prokaryotic density sample acquisition by the ice-core melter system. Each of those replicate sections had a cross-sectional area of $\sim 3 \mathrm{~cm} \times 3 \mathrm{~cm}$ and they represented $\sim 10 \%$ of our target ice-core section (2100-2480 m).

\subsection{Flow cytometer}

FCM measurements were made using a PhytoCyt flow cytometer (Turner Designs), which was developed in partnership with Accuri Cytometers (equivalent to the Accuri C6 BD model). This flow cytometer analyzes up to six simultaneous parameters, using two scatter measurements: $0^{\circ}$ light forward-scatter $\left(\mathrm{FSC}, \pm 15^{\circ}\right.$ ) and $90^{\circ}$ light side-scatter (SSC, $\pm 15^{\circ}$ ), and four fluorescence parameters: (1) green fluorescence (FL1; $530 \pm 15 \mathrm{~nm}$; excitation at $488 \mathrm{~nm}$ ), (2) yellow/ orange fluorescence (FL2; $585 \pm 20 \mathrm{~nm}$; excitation at 488 $\mathrm{nm})$, (3) red fluorescence-blue laser excitation (FL3; 670 LP $\mathrm{nm}$; excitation 488 (blue laser)), and (4) red fluorescencered laser excitation $(675 \pm 12.5 \mathrm{~nm}$; excitation $640 \mathrm{~nm}$ (red laser)). The PhytoCyt is equipped with a solid-state laser (20 $\mathrm{mW} ; 488 \mathrm{~nm}$; blue laser) and a diode laser (30 mW; 640 $\mathrm{nm}$; red laser). The detectors consist of a photodiode for the FSC from the blue laser, and a photomultiplier (PTM) for the SSC and the fluorescence emissions. Sample acquisition (24 bits and 7 decades digitization) and data analyses were performed using CFlow ${ }^{\circledR}$ software. This software allows the FCM parameters to be obtained as area $(A)$, height $(H)$ or width (W). All parameters were recorded on a seven-decade logarithmic scale for FCM controls and samples.

The instrument was installed in a clean bench with UV light (Labconco). Standard validation beads (Spherotech 8- and 6-Peaks Validation Beads) were analyzed daily to validate the system's fluidic performance and the instrument's level of sensitivity in detecting events. Milli-Q water blanks were measured before samples, and three back-flushes were performed between samples to prevent carry-over between them. 


\subsection{Nucleic acid stains}

The nucleic acid stains tested in this study were SYTOXgreen $^{\circledR}$ and SYBR-green- $\left.\right|^{\circledR}$ (Molecular Probes Inc). SYTOXgreen, the stain ultimately chosen, is an asymmetrically cationic triple-charged cyanine dye of 600 Dalton (Molecular Probes; Bojsen and others, 2013). SYTOX-green cannot cross the membranes of live cells and can only enter cells with compromised membranes (Roth and others, 1997; Lebaron and others, 1998a; Jones and Singer, 2001). It has a fluorescence quantum yield of 0.53 when bound to DNA (i.e. number of photons emitted/number of photons absorbed), with an excitation maxima at 480-505 nm, and emission maxima of $523 \mathrm{~nm}$ (Roth and others, 1997; Mortimer and others, 2000; Jones and Singer, 2001; Burnett and Beuchat, 2002). SYBR-green-I is a monomeric unsymmetrical cyanine dye that is capable of penetrating intact cell membranes. SYBR-green-I has been broadly used to quantify microorganisms in aquatic systems (Marie and others, 1999; Gasol and del Giorgio, 2000) and has a fluorescence quantum yield of 0.80 for DNA and 0.40 for RNA; it is maximally excited at 494-497 nm, and has an emission maximum at $521 \mathrm{~nm}$ (Molecular Probes; Lebaron and others, 1998b). Both stains were diluted in $0.2 \mu \mathrm{m}$ filtered $1 \times$ TBE (5.4 g Tris, 2.75 g Boric acid, 0.5 м EDTA, pH 8.0) before use.

\subsection{Epifluorescence microscopy (EFM)}

Samples for EFM were prepared inside a laminar-flow hood (Purifier horizontal clean bench, Labconco). The samples were stained for $20 \mathrm{~min}$ at a final concentration of $2.5 \mu \mathrm{M}$ for SYTOX-green and $1 \times$ for SYBR-green-I (Marie and others, 1999). Following staining, samples were filter concentrated onto Millipore Isopore ${ }^{\mathrm{TM}}$ Polycarbonate membrane filters (GTBP1300, $0.22 \mu \mathrm{m}$ pore size, $13 \mathrm{~mm}$ diameter, black) using Swinnex ${ }^{\circledR} 13$ filter holders and sterile syringes. Each filter was mounted on a glass slide with a drop of $0.2 \mu \mathrm{m}$ filtered antifade solution (1:1 glycerol, PBS and $0.1 \%$ p-phenylenediamine) before covering the filter with a $20 \mathrm{~mm}$ square coverslip. All prokaryotic cell counts were performed at $1000 \times$ with a Nikon Eclipse 80i epifluorescence microscope equipped with a Metal Halide lamp $\left(\right.$ X-Cite $\left.^{\circledR} 120 \mathrm{~W}\right)$, a 450-490 excitation filter (B-2A), a 515 barrier filter and a digital CCD Camera (Retiga 2000R Color Cooled). The total prokaryotic cell number was estimated on each filter by counting at least 500 cells per filter or up to 60 microscope fields, whichever occurred first. Controls consisted of filtered Milli-Q water (same volume as for samples) and were counted along with the samples on a daily basis. Because low cell concentrations were expected and only low sample volumes were available $(\sim 1-8 \mathrm{~mL})$, the Swinnex filter holders were modified to reduce the filtration area to $2.5 \mathrm{~mm}$ diameter when required. The small filtration area permitted the effective filter surface and counting effort to decrease when samples have low cell concentrations. A total of 110 WD samples were analyzed in parallel by FCM and EFM.

\subsection{Field emission scanning electron microscopy (FE-SEM)}

Equal volumes of 45 WD samples representing the Last Glacial Maximum (LGM) were combined to yield a $15 \mathrm{~mL}$ composite for this period (23 420-19978 a before $1950 \mathrm{CE}$ ) and equal volumes of 58 discrete samples representing
Termination I were combined to yield a $30 \mathrm{~mL}$ composite for this period (12 343-11 726 a before $1950 \mathrm{CE})$. These composite samples were fixed for $20 \mathrm{~h}$ in $5 \%(\mathrm{v} / \mathrm{v})$ glutaraldehyde. Cells were then filter concentrated onto Isopore ${ }^{\mathrm{TM}}$ filters (GTBP01300, $0.22 \mu \mathrm{m}$ pore size, $13 \mathrm{~mm}$ diameter, Millipore) with sterile Swinnex ${ }^{\circledR}$ filter holders (13 mm diameter, Millipore). The fixed cells were dehydrated by sequential passage through an ethanol gradient ranging from 10 to $100 \%$ ethanol (in increments of $10 \% ; 10 \mathrm{~m}$ at each concentration), dried in a Tousimis Samdri-795 critical point dryer, coated with Iridium using an Emitech K575X coater and visualized using a Zeiss Supra 55VP FE-SEM.

\subsection{Protocol development}

Different protocols were investigated to select the most accurate and precise method for the WD ice-core samples following the Minimal Information in FCM Experiments protocols (MIFlowCyt), outlined by Lee and others (2008). Data from FCM are often subjective and results can be ambiguous due to the lack of guidelines, controls and specific gating strategies in many publications (Lee and others, 2008; Müller and Tárnok, 2008; Nebe-von-Caron, 2009). Because of their small size, prokaryotic cells are at the limits of the detection sensitivity of most flow cytometers and require extra care to avoid and minimize interference factors (Müller and Tárnok, 2008; Nebe-von-Caron, 2009). For these reasons, and to provide the reader with a detailed protocol, FCM controls, optimizations, gating strategy and instrument setups are addressed in depth in this paper. All statistical tests were conducted using R-programming language (version 2.15.0 by R Foundation for Statistical Computing; R Development Core Team, 2012).

\subsubsection{Clean conditions}

A clean environment is required for unequivocal results, particularly when sample volume and cell density are low. These requirements are necessary not only to prevent contamination and increase the accuracy of cell quantification, but also to reduce the background noise on the FCM system, which improves sensitivity of the signal (Steen, 1992, 2000). We tested the efficacy of our clean methods using sterile Milli-Q water for FCM analysis and handled all samples in a laminar flow environmental chamber with UV light, using sterile materials (e.g., pipet tips, gloves, forceps) and appropriate sterile clothing, including face mask and hair cover. Events from $300 \mu \mathrm{L}$ of Milli-Q water were acquired by FCM using these conditions and compared with samples processed on a laboratory bench with no sterile protocols. Five replicates were included for each scenario. The FCM data were analyzed using a $t$-test.

\subsubsection{Instrument threshold level}

The instrument threshold allows the reduction of electronic noise and background signals inherent to samples (Gasol and del Giorgio, 2000; Shapiro, 2003) at the expense of instrument sensitivity. The threshold is the lowest signal of relative intensity units (RIU) at which an event can be recorded, and each channel has an inherent (intrinsic) noise floor in all flow cytometers. The detection of the noise floor was recorded under clean conditions with pure water samples (Milli-Q water), setting the threshold to its lowest value in 
the green fluorescence channel and choosing the appropriate boundary in trial Milli-Q samples by visual inspection.

\subsubsection{Establishing FCM controls}

Controls allow objective recognition of DNA stained prokaryotic cells through their visual discrimination of fluorescence output (Lee and others, 2008). Background signals that are inherent to samples and above the instrument threshold unavoidably occur. They have been reported in the literature and described as: non-specific stained particles, non-target cells, debris and/or unbound DNA stain (Klauth and others, 2004; Müller and Nebe-von-Caron, 2010). The limits of background noise were determined using three FCM controls: (1) blank control - to ensure proper clean conditions were followed, (2) background control - to detect signals produced by stained particles smaller than prokaryotic cells $(<0.22 \mu \mathrm{m})$, cellular debris and unbound stain (background controls are $0.22 \mu \mathrm{m}$ filtered samples), and (3) negative control - to identify the unstained events (negative events) and autofluorescent events in unstained samples.

\subsubsection{Selection of nucleic acid stain}

Ice-core samples often contain high concentrations of prokaryotic sized abiotic (dust) particles (e.g. Fischer and others, 2007). These abiotic particles can adsorb certain nucleic acid dyes and can also autofluorescence when exposed to low wavelength excitation light. These conditions can lead to: (1) false positive events in the prokaryotic cell size range, (2) a decrease of dye available to the targetcells, and (3) an increase in background noise (Klauth and others, 2004; Müller and Nebe-von-Caron, 2010). To address these issues, an experiment was designed to determine which nucleic acid dye, SYTOX-green or SYBRgreen-I, provides the most accurate cell counts in the presence of glacial sediments. These dyes were chosen because they have been used routinely to enumerate aquatic and soil bacteria by FCM.

Samples of bacterial cultures were serially diluted with Milli-Q water from $\times 10^{5}$ to $\times 10^{2}$ cells $\mathrm{mL}^{-1}$ (four different bacterial concentrations, three replicates each) followed by the addition of $0.2 \mathrm{mg}$ of $<63 \mu \mathrm{m}$ glacial sediments to 1.9 $\mathrm{mL}$ samples to obtain a final concentration $\sim x 10^{4}$ sediment particles $\mathrm{mL}^{-1}$ and a final sample volume of $\sim 2 \mathrm{~mL}$. These samples were then stained for $20 \mathrm{~min}$ at $20^{\circ} \mathrm{C}$ in the dark followed by FCM analysis. The final stain concentrations used were $0.5 \mu \mathrm{M}$ for SYTOX-green (Molecular Probes) and $1 \times$ for SYBR-green-I (Marie and others, 1997; Marie, 1999; stock concentration: $10000 \times$ ). Log/log linear regression between expected and observed cell densities from the FCM was compared with a 1:1 log/log linear relationship, which had an intercept $\left(\beta_{0}\right)$ equal to 0 and a slope parameter $\left(\beta_{1}\right)$ equal to 1.

\subsubsection{Optimization of the stain concentration}

Results from previous experiments showed that SYTOXgreen revealed insignificant interference from glacial sediment, hence, optimization of stain concentration focused on this dye only. The recommended SYTOX-green concentration for bacteria ranges from 5 to $1 \mu \mathrm{M}$ (Molecular Probes). We tested final concentrations: 1, 0.5, 0.25, 0.1, $0.05,0.025$ and $0.01 \mu \mathrm{M}$. SYTOX-green stocks ( $5 \mathrm{~mm}$ solution in DMSO) were diluted with $0.2 \mu \mathrm{m}$ filtered $1 \times \mathrm{TBE}(5.4 \mathrm{~g}$ Tris, $2.75 \mathrm{~g}$ Boric acid, $0.5 \mathrm{M}$ EDTA, $\mathrm{pH}$ 8.0) and stored at $4^{\circ} \mathrm{C}$ in the dark before use. The final stain concentrations were tested on $1 \mathrm{~mL}$ samples of bacterial culture $\left(1.3 \times 10^{5}\right.$ cells $\mathrm{mL}^{-1}$ ). The samples were stained with SYTOX-green, vortexed, incubated for $20 \mathrm{~min}$ in a sterile BD Falcon tube $(12 \mathrm{~mm} \times 75 \mathrm{~mm})$ at $20^{\circ} \mathrm{C}$ (room temperature) in the dark, and analyzed immediately by FCM.

\subsubsection{Optimization of the fluidic settings in WD ice-core samples}

The fluidic settings were performed on actual WD ice-core samples because these settings could modify cell detection and background noise (Gasol and del Giorgio, 2000; Shapiro, 2003). The flow rate that is used to enumerate pro-

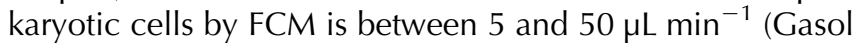
and del Giorgio, 2000). Low flow rates are typically used for dense prokaryotic cell samples to ensure there are no coincident particle counts; higher flow rates can be used for low density samples. Prokaryotic cells have been found in Antarctic ice-core samples at densities varying from $~ 1$ up to $10^{5}$ cells $\mathrm{mL}^{-1}$ (Christner and others, 2006; Priscu and others, 2007; Segawa and others, 2010); hence it was imperative that an appropriate flow rate was chosen for the samples being processed.

In addition to the determination of a proper flow rate, we had to ensure that our sample prefiltration (to eliminate large particles that could clog the fluidics system) did not interfere with actual prokaryotic enumeration and background noise. We developed a single experimental design to determine both the effects of flow rate and pre-filtration on prokaryotic density (cells $\mathrm{mL}^{-1}$ ) and background noise events (events $\mathrm{mL}^{-1}$ ). The experiment was completely randomized with two fixed factors, flow rate and pre-filtration, each one with three treatments. For the flow rate factor, the treatments were: 14,32 and $50 \mu \mathrm{L} \mathrm{min}{ }^{-1}$. For the pre-filtration factor, the treatments were: no-pre-filtration, $30 \mu \mathrm{m}$ pre-filtration and $100 \mu \mathrm{m}$ pre-filtration. Each combination (9) had three replicates $(3 \times 9)$. The response variables were $(1)$ prokaryotic density and (2) background noise events. A sample volume of $50 \mu \mathrm{L}$ was analyzed for each of the 27 samples.

\subsubsection{Validation of the measurement technique}

All the samples used to validate the method were pre-filtered using a $30 \mu \mathrm{m}$ mesh sterile BD Falcon Tube with Cell Strainer Cap and stained for $20 \mathrm{~min}$ in the dark at room temperature $\left(\sim 20^{\circ} \mathrm{C}\right)$ with SYTOX-green (final concentration of $\left.0.05 \mu \mathrm{M}\right)$. We determined FCM detection limits, the minimum cell concentration level at which the cell counts can be reliably detected, by comparing the observed versus expected cell densities of WD ice-core samples and bacterial cultures with added sediment. The samples were serially diluted with Milli-Q water to yield final cell concentrations ranging from $10^{6}$ to $10^{0}$ cells $\mathrm{mL}^{-1}$. A constant volume of $1600 \mu \mathrm{L}$ was analyzed at a flow rate of $50 \mu \mathrm{L} \mathrm{min}^{-1}$ for each sample by FCM.

The relative precision of our method was computed as the coefficient of variation $(\widehat{\mathrm{CV}}=(\mathrm{SD} / \bar{X}) \times 100)$; $\mathrm{CV}$ is the best precision estimator to describe variation that is proportional to the mean (Shapiro, 2003; Bolker, 2008). By their nature, FCM counts should follow a Poisson sample distribution, a discrete distribution that describes count processes well. A characteristic of the Poisson distribution is that the variance is equal to its mean $\left(\sigma^{2}=\mu\right)$. In other words, the variance depends on the number of counts. Therefore, the Poisson 
distribution becomes more regular as the expected number of counts increases (Shapiro, 2003; Bolker, 2008); hence, the larger the number of cells counted by FCM, the greater the relative precision. The $\mathrm{CV}$ was calculated at different cell concentration factors in WD ice-core samples. A total of 23 random WD ice-core samples were analyzed with 2-4 replicates (replication depended on sample availability).

Accuracy was obtained using a log/log serial dilution curve to ensure that there was a log/log linear correlation between observed and expected bacterial densities over a range of cell concentrations. WD ice-core samples and bacterial cultures (with glacial sediments) were serially diluted by Milli-Q water from $\times 10^{5}$ to $\times 10^{2}$ cells $\mathrm{mL}^{-1}$ and three replicates were analyzed at each concentration by FCM. Accuracy was assessed by comparing the slope and intercept values of the $1: 1 \mathrm{log} / \mathrm{log}$ regression with the log/log linear relationship between the observed and expected cell densities. The method was considered accurate if the 95\% confidence intervals $(\mathrm{Cl})$ for both estimates, slope and intercept, includes the values of the $1: 1 \mathrm{log} / \log$ linear regression $\left(\beta_{0}=0 ; \beta_{1}=1\right)$.

\subsubsection{Gating strategy}

An important principle of FCM data analysis is to visualize the cells of interest while eliminating results from unwanted particles (non-target particles), in this case: cellular and abiotic debris, sediment particles and autofluorescent cells and particles (Shapiro, 2003; Lee and others, 2008). Six gates were set to obtain target-cell (non-photosynthetic prokaryotes) counts from WD ice-core samples. The final gating strategy was validated and described here, in the result section, using WD samples from depths ranging between 1307 and $2709 \mathrm{~m}$.

\section{RESULTS}

\subsection{Clean conditions and instrument threshold}

There was significant evidence of an increase of background noise when the clean protocol was not used (one sided $p$ value $<0.05$ from a two-sample $t$-test; Fig. 1c) indicating that the flow cytometer must be operated in a particle free environment and protective clothing must be worn.

The instrument threshold was set on the same primary parameter (trigger signal) used to discriminate prokaryotic cells. This threshold was set on the green fluorescence channel (the FL1 detector) because SYTOX-green and SYBR-green-I have their maximum wavelength emission at 524 and $521 \mathrm{~nm}$, respectively. The inherent noise floor for the green fluorescence channel was visualized by analyzing Milli-Q water with no stain and adjusting the threshold to its lowest value (10 RIU) in this FCM; Fig. 1a). The noise floor was subtracted by setting the threshold above the electronic noise in the green fluorescence channel. On our instrument, this resulted in threshold values of 750 RIU in the green fluorescence channel (vertical red line drawn on count versus green fluorescence plot; Fig. 1). Figure $1 \mathrm{~b}$ shows the acquisition of events in a Milli-Q water sample after applying the instrument threshold at clean conditions where no events are recorded. It should be noted that the background noise is not all electronic and can increase significantly if clean protocols are not followed (Fig. 1c).

\subsection{Establishing FCM controls}

Three controls were established in this study (Fig. 2): (1) Milli$\mathrm{Q}$ water blank controls, (2) background control consisting of sample filtered through a $0.22 \mu \mathrm{m}$ pore size sterile filter followed by SYTOX-green staining, and (3) a negative control consisting of an unstained sample, which allows identification of autofluorescent particles and abiotic events. The background and negative controls provide information to set the boundaries of gate $1(\mathrm{P} 1)$ where the expected positive events should fall (Fig. 2). This set of controls permits the recognition of DNA stained prokaryotic cells through their visual discrimination and the development of a protocol based on the outlined requirements in Minimal Information in FCM Experiments protocols (MIFlowCyt; Lee and others, 2008).

\subsection{Selection of the nucleic acid stain}

Quantitative results from the experiment to assess which stain, SYTOX-green or SYBR-green-I, accurately enumerate bacterial cells in the presence of sediments showed that: (1) SYTOX-green stained samples counted using gate 1 (P1) revealed similar counts with and without the addition of sediments (Fig. 3a) and (2) when SYBR-green-I was used to stain cells in the presence of sediments, the cell density decreased by factors of 28.3, 33.3 and 13.1 at tested prokaryotic densities of $10^{3}, 10^{4}, 10^{5}$, respectively; no cells were counted at the expected cell density of $10^{2}$ (Fig. 3b).

Statistical analysis, log/log linear regressions and $\mathrm{Cl}$, were used to assess the enumeration accuracy by both stains in the presence of sediments. We estimated the log/log linear regression between expected bacterial density (sample without sediments) and observed bacterial density (sample with sediments). We then compared the estimated log/log linear regressions with the parameters of the $1: 1 \log / \mathrm{log}$ linear relationship. The parameters for the $1: 1 \mathrm{log} / \mathrm{log}$ linear regression are an intercept $\left(\beta_{0}\right)$ of 0 and a slope $\left(\beta_{1}\right)$ of 1 . We expected those values to be included in the $95 \% \mathrm{Cl}$ of the estimated log/log linear regressions. The estimated log/log linear regressions for the observed versus expected bacterial density were:

$$
\begin{aligned}
\widehat{\log (y)_{\text {SYTOX green }}} & =-0.16+1.02 \log (x) ; \\
\operatorname{SE}\left(\hat{\beta}_{0}\right) & =0.19 \operatorname{SE}\left(\hat{\beta}_{1}\right)=0.02 ; R^{2}=0.99 \\
\widehat{\log (y})_{\text {SYBR green I }} & =-7.91+1.43 \log (x) ; \\
\operatorname{SE}\left(\hat{\beta}_{0}\right) & =0.73 \operatorname{SE}\left(\hat{\beta}_{1}\right)=0.07 ; R^{2}=0.97
\end{aligned}
$$

Here, only the estimated $95 \%$ CI of SYTOX-green log/log linear regression included the values for the $1: 1 \mathrm{log} / \log$ linear relationship $\left(\hat{\beta}_{0}=[(-0.58)-(0.25)] ; \hat{\beta}_{1}=[(0.97)-(1.07)]\right)$. In contrast, the SYBR-green-I regression did not include the values of the $1: 1 \mathrm{log} / \log$ regression in the $95 \% \mathrm{Cl}$ of the intercept and slope $\left(\hat{\beta}_{0}=[(-9.55)-(-6.27)] ; \hat{\beta}_{1}=\right.$ $[(1.26)-(1.60)])$. These results indicate that SYTOX-green accurately stains bacteria in the presence of glacial sediments, and SYBR-green-I showed non-specific staining for sediments. In addition, our microscopic inspection of samples showed that sediment particles and debris were not stained by SYTOXgreen, whereas SYBR-green-I stained sediment particles and debris, which agrees with the results of other studies (Wobus 

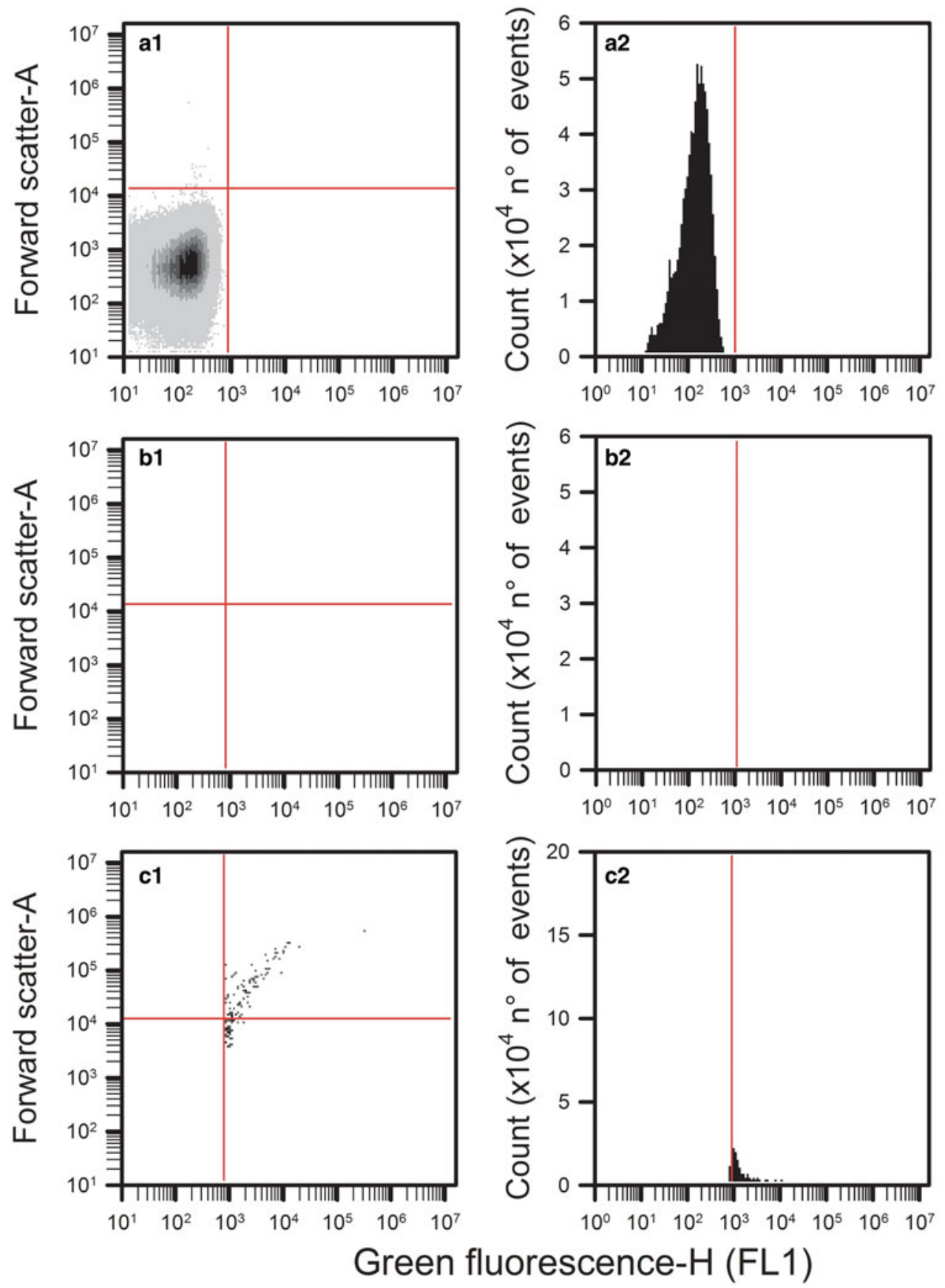

Fig. 1. Cytograms showing results of forward-scatter-A and total particle counts versus green fluorescence-H $(H=$ height) used to set instrument thresholds. (a1, a2): The equipment noise from an unstained Milli-Q water sample (blank); red lines were drawn to show the boundaries of equipment noise. (b1, b2): Unstained Milli-Q water sample (blank) after setting instrument threshold level at 750 RIU in FL1-H (green-fluorescence). (c1, c2): Unstained Milli-Q water sample with instrument threshold level set but without the use of clean protocols.

and others, 2003; Klauth and others, 2004; Morono and others, 2013).

\subsection{Stain concentration}

Seven SYTOX-green concentrations (1, 0.5, 0.25, 0.1, 0.05, 0.025 and $0.01 \mu \mathrm{M})$ were tested using WD ice-core samples to determine the optimal stain concentration. The stain concentrations that presented the highest mean and median gate 1 (P1) intensities of green fluorescence were 0.1 and $0.05 \mu \mathrm{m}$ (Table 1). Although both of these concentrations produced high fluorescence yields and broad spectral difference between negative and positive events, the $0.05 \mu \mathrm{m}$ treatment produced counts closer to the actual cell numbers $\left(1.3 \times 10^{5}\right.$ cells $\mathrm{mL}^{-1}$ ) present in the samples, which was determined by direct microscopic counting. Results from these experiments led us to select $0.05 \mu \mathrm{m}$ stain concentration for prokaryotic cell enumeration in the analyzed ice cores.

SYTOX-green requires permeable cells to allow the stain to enter the cell and bind to DNA. Interestingly, we obtained accurate FCM cell counts on cells in the WD ice core without using additional methods, such as detergents or heat, to permeabilize the membrane, indicating that the cells already had compromised membranes, or that the $2 \%$ formalin fixation permeabilized the cells. To test the effect of formalin fixation, we compared cell density of the same WD samples with and without $2 \%$ formalin. The experiment showed that formalin fixation did not increase the degree 

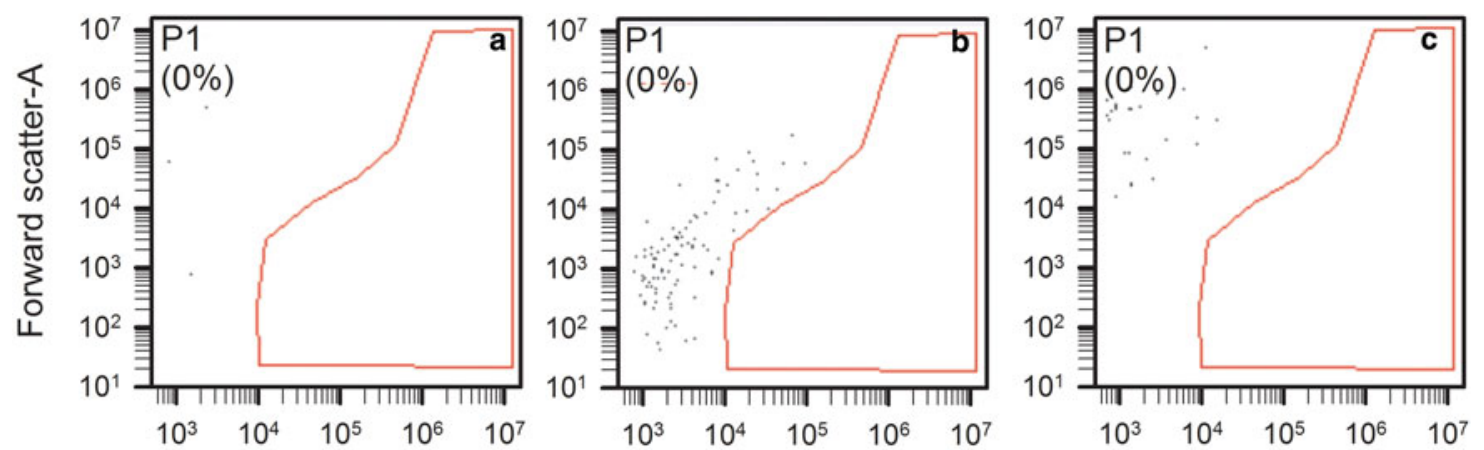

Green fluorescence-H (FL1; SYTOX-green)

Fig. 2. Cytograms on green fluorescence-H versus forward scatter-A density-plots of a WD sample. (a) Blank control = unstained Milli-Q water sample. (b) Background control = stained $0.2 \mu \mathrm{m}$ filtered WD sample. (c) Negative control = unstained WD sample. Gate 1 (P1; red polygon) is used to keep outside background noise and negative events inherent to samples and is defined using these controls. Positive DNA stained events should fall in P1.
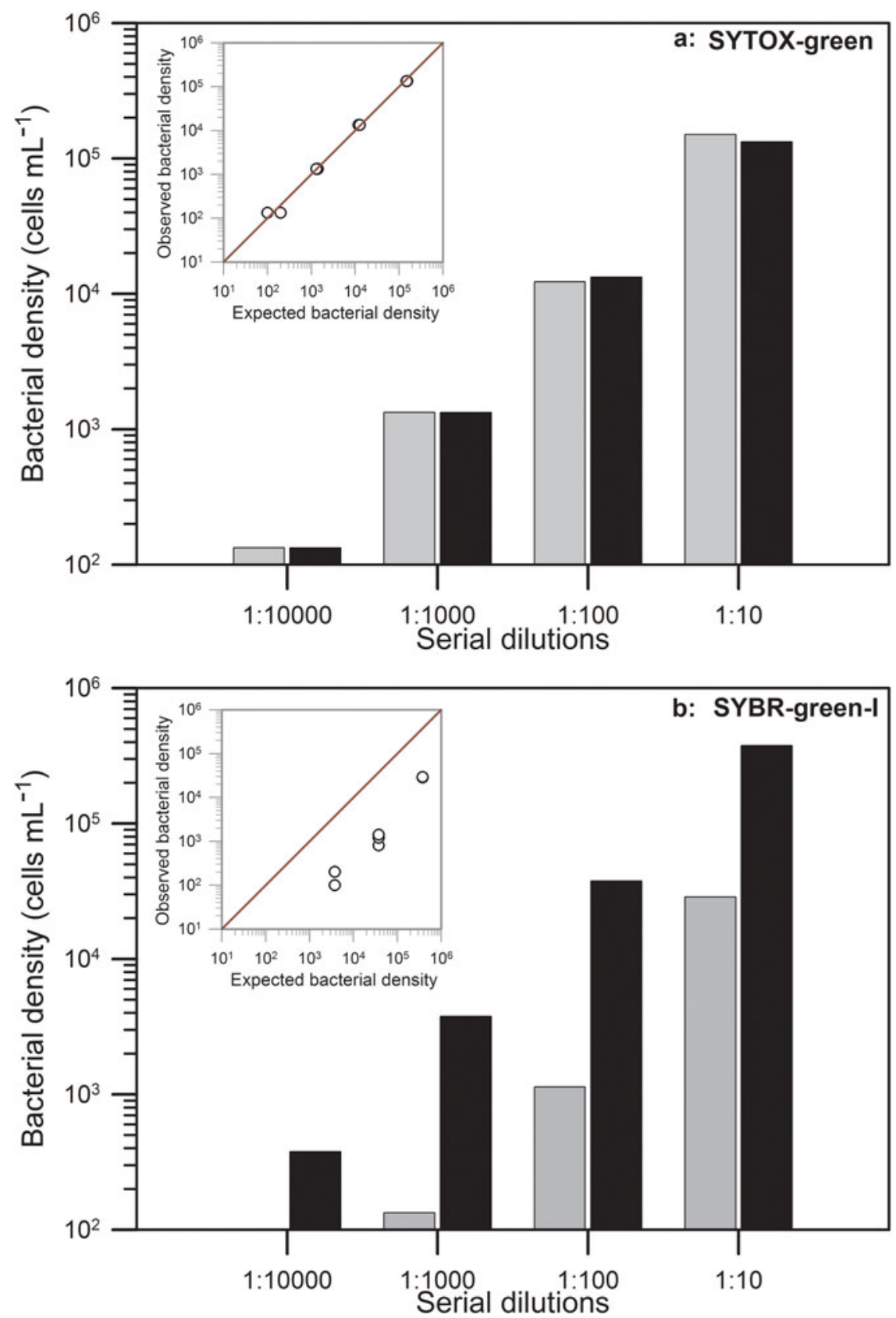

Fig. 3. Bacterial density in the presence of sediments for samples stained with SYTOX-green (panel a) and SYBR-green-I (panel b) in samples diluted with Milli-Q water. Gray bars correspond to bacterial density quantified for each stain in the presence of sediments; black bars correspond to the expected bacterial density. Inserts show a 1:1 log/log linear regression (red line) and actual observations (dots). 
Table 1. Optimization of stain concentration

\begin{tabular}{lccl}
\hline $\begin{array}{l}\text { SYTOX green final } \\
\text { concentration }\end{array}$ & $\begin{array}{l}\text { Green } \\
\text { fluorescence } \\
\text { Mean; RIU }\end{array}$ & $\begin{array}{l}\text { Green } \\
\text { fluorescence } \\
\text { Median; RIU }\end{array}$ & $\begin{array}{l}\text { Bacterial } \\
\text { density } \\
\text { cells mL }{ }^{-1}\end{array}$ \\
\hline 0.01 & 71462 & 60555 & $1.45 \times 10^{5}$ \\
0.025 & 66901 & 60050 & $1.29 \times 10^{5}$ \\
0.05 & 75968 & 69752 & $1.28 \times 10^{5}$ \\
0.1 & 76213 & 70241 & $1.06 \times 10^{5}$ \\
0.25 & 52936 & 46191 & $9.63 \times 10^{4}$ \\
0.5 & 56016 & 49805 & $8.99 \times 10^{4}$ \\
1 & 49671 & 43363 & $8.06 \times 10^{4}$ \\
\hline
\end{tabular}

Mean and median fluorescence (RIU, relative intensity units) of P1 gate (prokaryotic events) in a WD sample stained with different concentrations of SYTOX green. The measured prokaryotic density of each sample is also presented. Target cell density was $1.3 \times 10^{5}$ cells $\mathrm{mL}^{-1}$.

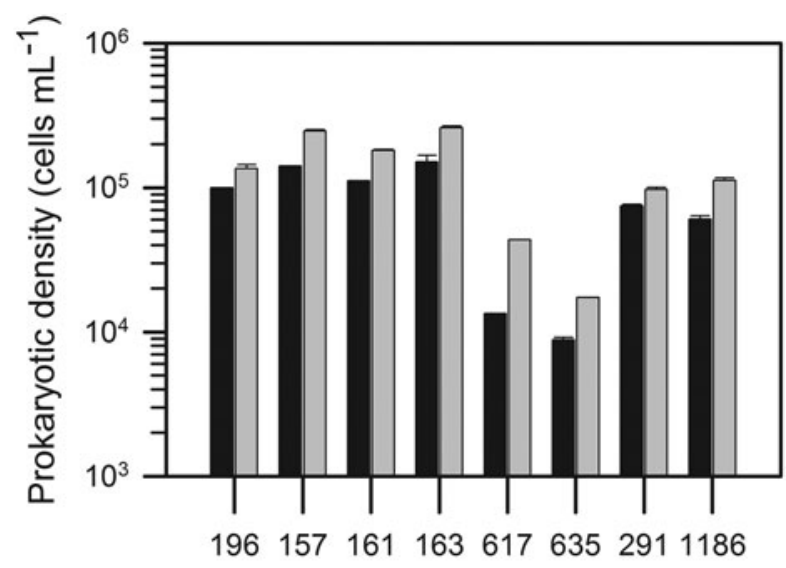

Sample number

Fig. 4. Prokaryotic density comparison of selected WD ice-core samples with and without formalin (formalin fixed = black bars; unfixed $=$ gray bars). All the samples were stained with SYTOXgreen $(0.05 \mu \mathrm{m}$ final concentration) and enumerated by FCM.

of permeabilization indicating that the membranes of cells in the WD samples had compromised membranes before formalin was added (Fig. 4). Formalin fixation decreased cell density by a factor mean of 1.85 (range 1.36-3.25) in all the tested samples (Fig. 4). Examination of WD samples by FE-SEM showed that the cell membranes had different degrees of membrane and cell integrity, which confirms permeabilization of WD prokaryotic cells (Fig. 5).

\subsection{Optimization of the fluidic settings on WD ice- core samples: flow rate and pre-filtration}

A comparison of three flow rates $\left(14,32\right.$ and $\left.50 \mu \mathrm{L} \mathrm{min}^{-1}\right)$ revealed no significant evidence of differences in measured cell-densities among the flow rates tested ( $p$-value $>0.1$; F-test), implying that the flow rates tested did not have an effect on cell enumeration of WD samples. The flow rates tested did, however, significantly influence the amount of background noise ( $p$-value $<0.01 ; F$-test). The background noise events increased when the flow rate decreased; a flow rate of $14 \mu \mathrm{L} \mathrm{min}{ }^{-1}$ has a median noise event density 1.71 times larger than a flow rate of $50 \mu \mathrm{L} \mathrm{min}^{-1}$. We selected a flow rate of $50 \mu \mathrm{L} \mathrm{min}{ }^{-1}$ to enumerate prokaryotic cells in the WD ice-core samples because it did not significantly influence prokaryotic cell counts, and it provided an adequately low background to detect prokaryotes in samples with low cell concentrations.

The comparison of pre-filtration techniques showed that pre-filtration with a $30 \mu \mathrm{m}$ filter yielded no significant differences in cell counts from samples that were not pre-filtered ( $p$-value $<0.01 ; F$-test). In contrast, pre-filtration yielded 1.6 times lower background noise than no-pre-filtration. Consequently, samples were always prefiltered through sterile BD Falcon $12 \mathrm{~mm} \times 75 \mathrm{~mm}$ tubes with $30 \mu \mathrm{m}$ cell Strainer Cap to prevent clogging of the fluidic system and decrease background noise events.

\subsection{Validation of the measurement technique}

The minimum detection limit was determined by counting serial dilutions of WD ice-core samples and bacterial cultures with glacial sediments. Four samples were serially diluted (10-fold) to obtain a range of cell densities from $\sim 10^{6}$ to $10^{0}$ cells $\mathrm{mL}^{-1}$. Visual inspection of linearity between log-observed and log-expected cell densities indicates that the lowest cell density that could be detected accurately is $\sim 10^{2}$ cells $\mathrm{mL}^{-1}$ when at least 180 cells are counted by FCM ( 1.6 mL sample counted; $32 \mathrm{~min}$ ) (Fig. 6a).

The $C V$ was calculated on 23 random samples with cell concentrations from $10^{2}$ to $10^{5}$ cells $\mathrm{mL}^{-1}$. The actual counted cells by FCM were from 182 to 25307 . When using FCM, the estimated $\mathrm{CV}$ for cell densities shows a mean of $3.3 \%$ with a range of $0.5-6.2 \%$. The $95 \% \mathrm{Cl}$ range for the mean of the $\mathrm{CV}$ was $(2.6-4.1 \%)$, and the $99 \% \mathrm{Cl}$ was $(2.3-4.4 \%)$; both of them are narrow and do not exceed $5 \%$. The $\mathrm{CV}$ is in agreement with the $<5 \%$ precision calculated for FCM by others (Gasol and del Giorgio, 2000; Wang and others, 2010). In addition, we estimated the $\mathrm{CV}$ for cell density when using EFM on replicates (5-10) from samples with cell densities between $10^{1}$ and $10^{3}$ cells $\mathrm{mL}^{-1}(\mathrm{CV}>28 \%$, maximum $\mathrm{CV}=72 \%)$. As expected, the $\mathrm{CV}$ for cell densities when using EFM was higher than when using FCM. The CV for EFM has been reported to be higher $(>10 \%)$ than FCM at cell densities of $10^{6}$ cells $\mathrm{mL}^{-1}$ when counting at least 300 cells per filter (Kirchman and others, 1982; Kirchman, 1993).

To assess accuracy of the FCM protocol, the samples were serially diluted (10-fold) to obtain a density range between $10^{6}$ and $10^{2}$ cells $\mathrm{mL}^{-1}$. When comparing log-observed cell densities with the log-expected cell densities, no evidence of differences between log-observed and log-expected cell densities was found (two sided $p$-value $=0.89$, from a two sample $t$-test). In addition, the $\log / \log$ linear regression between expected and observed cell densities confirmed a high degree of accuracy for the method; the log/log linear regression showed no deviation from linearity $\left(r^{2}=0.995\right.$, $p$-value $<0.01$; Fig. $6 \mathrm{~b}$ ) and the residual plots show random scatter and no systematic trends (data not shown). The estimated slope was 0.985 with a $95 \% \mathrm{Cl}$ range of $(0.962-$ 1.001), which is narrow and contains the slope of a 1:1 log/ log linear regression (Fig. 6b). The computed intercept was 0.048 with a $95 \% \mathrm{Cl}$ range of $[(-0.178)-(0.273)]$, which includes zero. The estimated log/log linear equation for the observed versus expected bacterial density was:

$$
\begin{aligned}
\widehat{\log (y)})_{\text {accuracy assay }} & =0.048+0.985 \log (x) ; \\
\operatorname{SE}\left(\hat{\beta}_{0}\right) & =0.110, \operatorname{SE}\left(\hat{\beta}_{1}\right)=0.01
\end{aligned}
$$



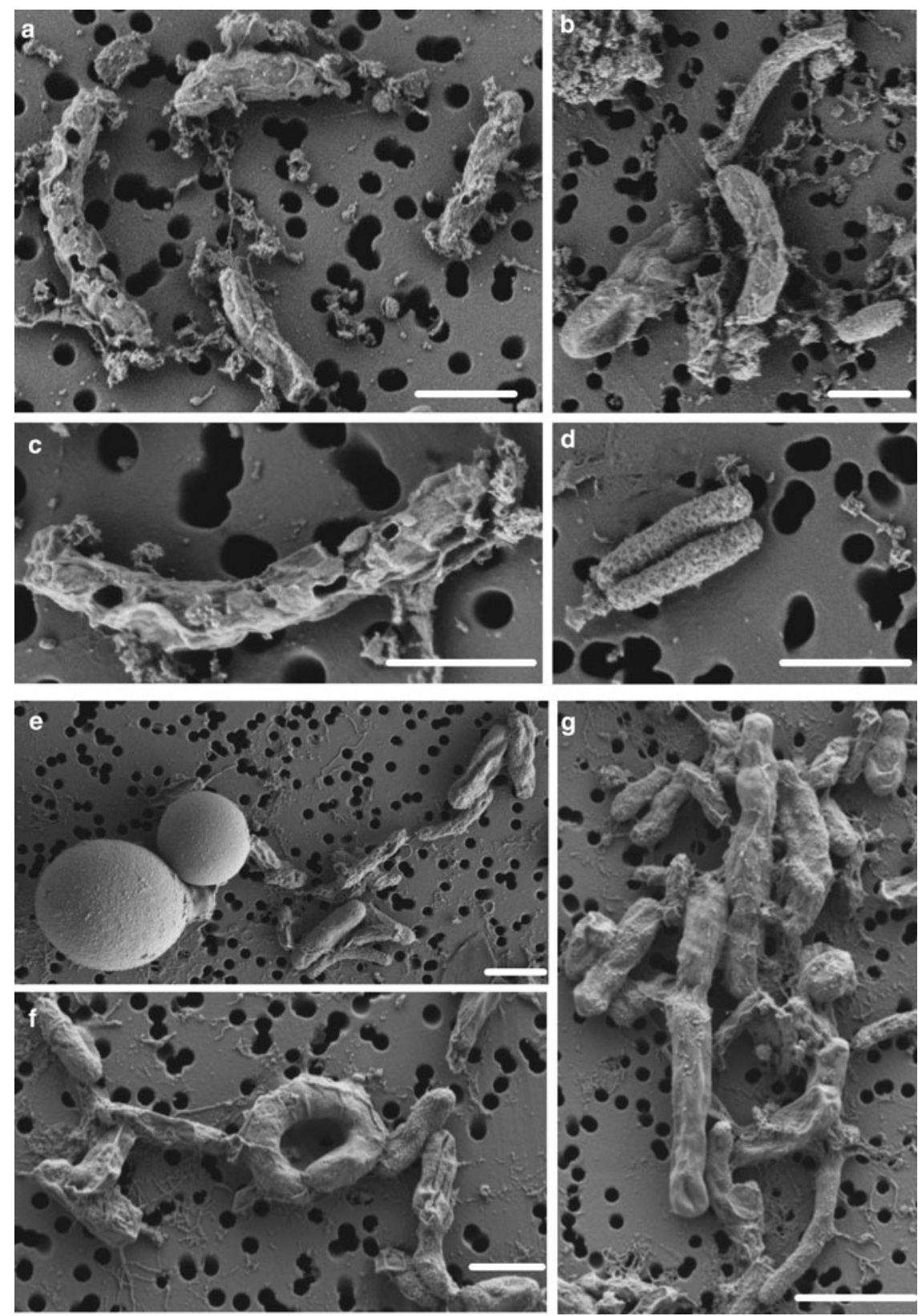

Fig. 5. FE-SEM images of prokaryotic cells from WD samples. (a-d) prokaryotic cells from Termination I (12.3-11.7 ka before 1950 CE), (e-g) prokaryotic cells from Last Glacial Maximum period (23.4-19.9 ka before $1950 \mathrm{CE}$ ). White scale bars represent $1 \mu \mathrm{m}$.

\subsection{Gating strategy}

The final gating strategy was based on the above controls, target cells (non-photosynthetic prokaryotes) and the above protocol assessments, all of which allowed the optimal distinction of DNA-stained non-photosynthetic prokaryotic cells. The six gates we used are described in sequential order. The final gating strategy was validated using 80 WD samples from different depths that were concurrently quantified by EFM. A WD sample is shown as visual examples through the gating strategy description.

Step 1: Gate 1 is a polygon (P1) that removes the background noise inherent to samples and selects the SYTOX positive events (DNA stained events). It is defined using the described blank, background and negative controls. P1 is defined on a density plot of green fluorescence-H (SYTOXgreen emission) versus FSC-A channel (Figs 2, 7).

Step 2: Gate 2 is a polygon (P2) defined on a dot-plot of green versus red fluorescence (FL3; >670 nm; Fig. 8).
Events are acquired from a stained sample and plotted in the dot-plot. That allows for optimal visual differentiation of 'noise particles'. P2 contains noise events, which have been described as sediments and appear in a diagonal line with relatively more red fluorescence than that for prokaryotic cells (Gasol and others, 1999; Gasol and del Giorgio, 2000). Then P2 is gated out from P1, which prevents noise events that can interfere with the counts.

Step 3: Gate 3 is a horizontal marker (M3) defined on a histogram-plot of count versus green fluorescence-H (SYTOX-green) (Fig. 9). M3 is defined as a horizontal marker to discriminate the prokaryotic cluster from cellular debris and eukaryotic cells, which have relatively more green fluorescence than the prokaryotic cluster. In the histogram-plot, the events present in gate $\mathrm{P} 1$ (positive SYTOX events) minus P2 events (noise particles) are plotted, and the horizontal marker is drawn around the prokaryotic cluster (Fig. 9). 

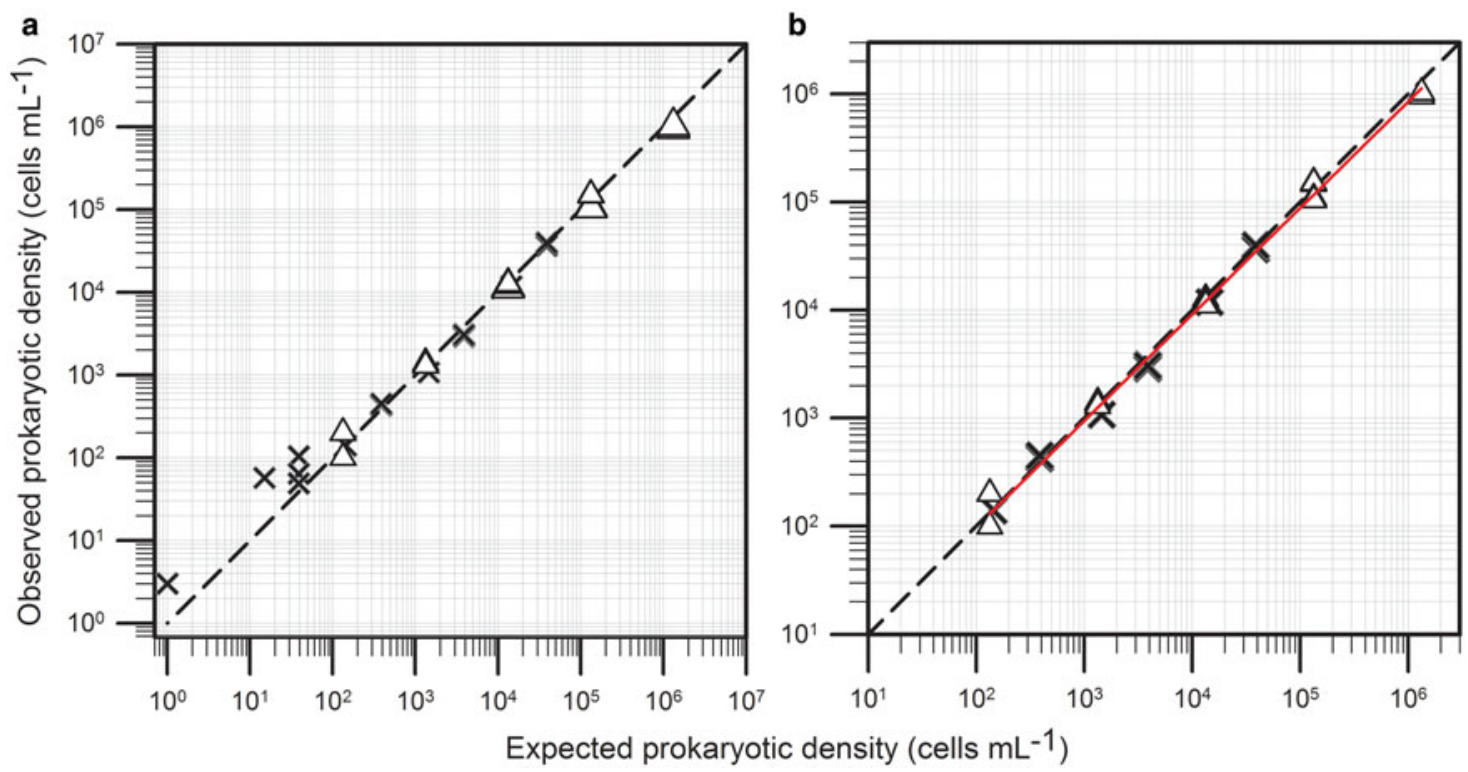

Fig. 6. Log-scale scatter plots of observed versus expected cell densities used to determine minimum detection limit (a) and accuracy (b) on serial dilutions (with Milli-Q) of WD ice-core samples $(X)$, and samples from bacterial cultures with glacial sediments $(\Delta)$ ). Black short-dash line corresponds to the 1:1 log/log relationship (slope $=1$ and intercept $=0$ ); red line on $(b)$ corresponds to the accuracy assay log/log linear regression $\left(r^{2}=0.995, p\right.$-value $<0.01, \hat{\beta}_{0}: 0.048$ and $\left.\hat{\beta}_{1}: 0.985\right)$.

Step 4: In order to exclude autofluorescent pigmented prokaryotes and pico-eukaryotes from the prokaryotic cluster, gates 4, 5 and 6 were defined by quadrants (Q4, Q5 and Q6). Pigmented prokaryotes and pico-eukaryotes can have the same sizes and their nucleic acids can also be stained by SYTOX-green. Photoautotrophic pigments are identified using the events in gate M3 (P1 included and P2 excluded), those events are plotted on three plots: (1) FSC-A versus
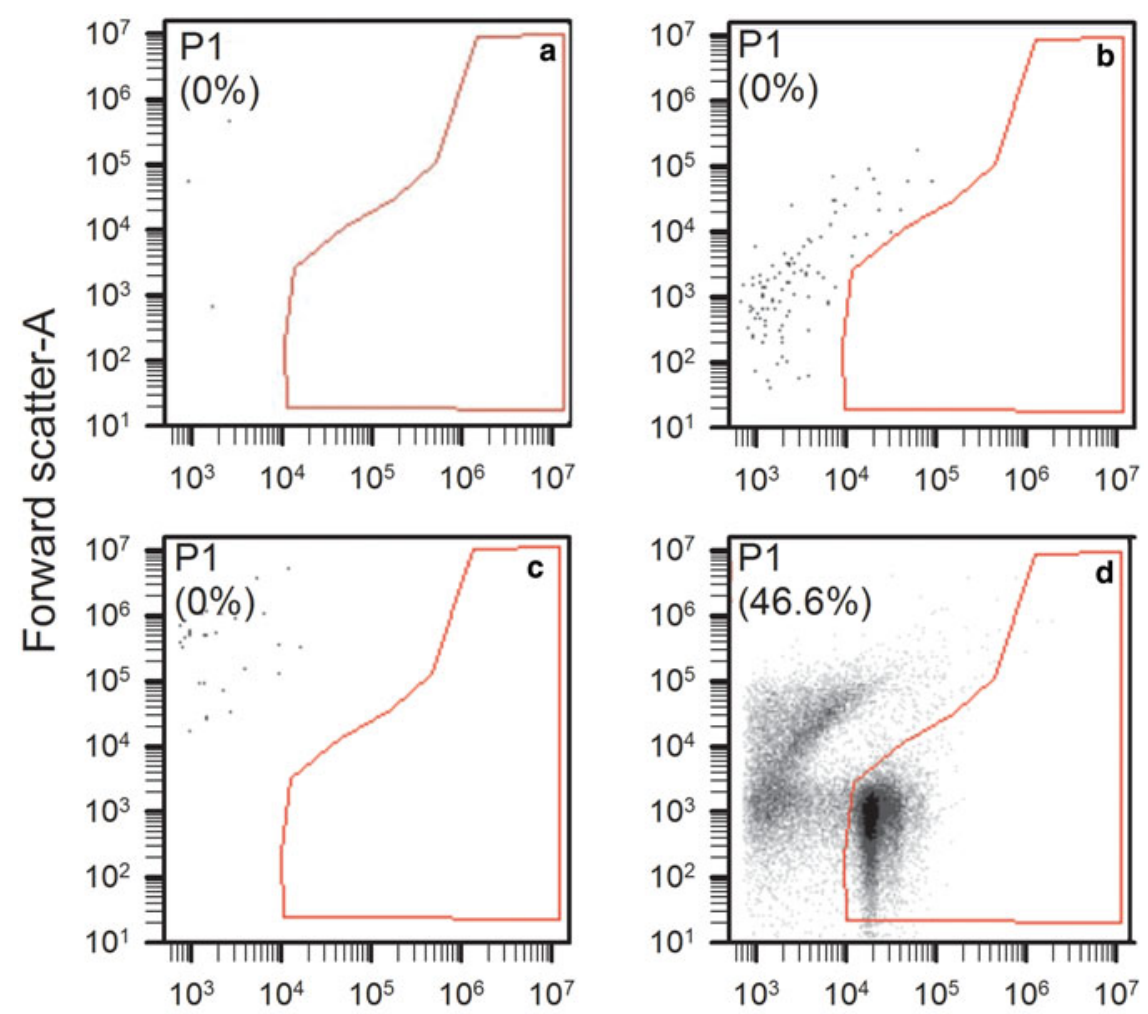

Green fluorescence-H (FL1; SYTOX-green)

Fig. 7. Cytograms of two WD ice-core samples to select SYTOX-green positive events. Gate 1 (P1, red polygon) is used to include only positive SYTOX-green events and to remove background noise. $\mathrm{P} 1$ is defined on a density-plot of green-fluorescence- $\mathrm{H}$ ( $\mathrm{H}=$ height) versus Forwardscatter-A ( $\mathrm{A}$ = area). (a) Milli-Q as blank control. (b) Background control (0.2 $\mu \mathrm{m}$ filtered stained sample). (c) Negative control (unstained sample). (d): SYTOX-green events from a WD sample. Percentages of events in P1 are presented between parentheses. 

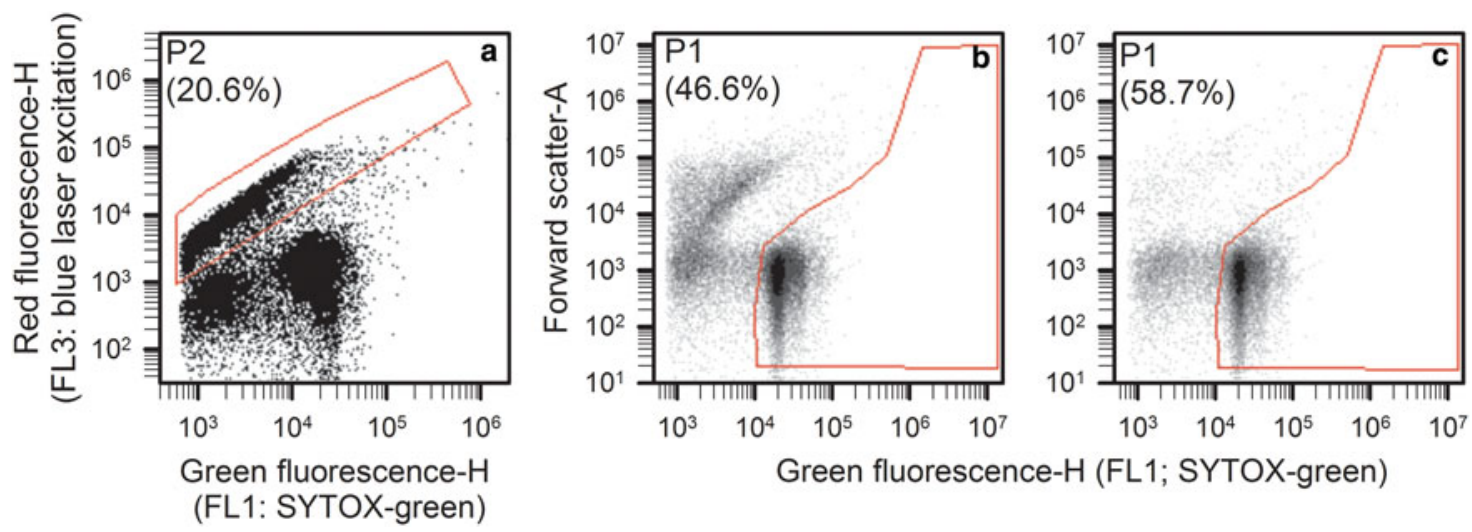

Fig. 8. Cytograms of a WD sample stained with SYTOX-green to select and remove noise particles. (a) Gate 2 (P2), which is defined on a dotplot of green fluorescence-H $(\mathrm{H}$ = height) versus red fluorescence-H (blue laser excitation; FL3) and includes 'noise particles' events (diagonal box above the positive SYTOX events). (b-c): Positive SYTOX-green events and P1 on a density-plot of green-fluorescence-H versus forwardscatter-A. (b) Positive control before applying P2 gate. (c) Positive control after gating out P2 events. Percentages of events in each gate are presented between parentheses.

yellow/orange fluorescence (FL2-H, Em. $585 \pm 20 \mathrm{~nm}$, Ex. $488 \mathrm{~nm}$ ) to detect cells with Phycoerythrin (Phy-E; Figs 10a, d); (2) FSC-A versus red fluorescence-blue laser excitation (FL3-H, Em. >670 nm, Ex. $488 \mathrm{~nm}$ ) to detect cells with autofluorescent chlorophyll-a (Chl-a; Figs 10b, e); and (3) FSC-A versus red fluorescence-red laser excitation (FL4-H, Em. 675 $\pm 12.5 \mathrm{~nm}$, Ex. $640 \mathrm{~nm}$ ) to detect cells with Phycocyanins (Phy-C, Figs 10c, f). Q4, Q5 and Q6 are the positive pigment events at each plot, respectively and defined by the upper left (UL) and upper right (UR) quadrant markers at each plot (Fig. 10). After the detection of the autofluorescent events, they are removed from the prokaryotic cluster.

Step 5: Finally, prokaryotic density is quantified in gate 3 (M3) after removing gates 4, 5 and 6 (Q4, Q5 and Q6), and plotted in a density-plot of green fluorescence-H versus FSC-A (Fig. 11). As an example, four WD ice-core samples, from different depths that display the final non-photosynthetic prokaryotic events are presented in Figure 11. They show the typical two sub-group pattern of low-nucleic acid content and high-nucleic acid content prokaryotes, which have been discriminated in most aquatic samples (Li and others, 1995; Gasol and others, 1999; Gasol and del Giorgio, 2000; Lebaron and others, 2001, 2002). In contrast to these studies, we observed other subgroups differentiated by green fluorescence throughout the WD samples.

\subsection{Final protocol description}

The thresholds are set on the green fluorescence channel $(\mathrm{FL} 1-\mathrm{H})$ at $750 \mathrm{RIU}$. Sample $(2 \mathrm{~mL})$ is then pipetted using sterile filtered tips from the glass vial to a clean tube with a $30 \mu \mathrm{m}$ mesh for pre-filtration. From that tube, $150 \mu \mathrm{L}$ is analyzed as the negative control (unstained sample), and the remaining $1800 \mu \mathrm{L}$ is stained with SYTOX-green. A background control is obtained from the same sample vial by pipetting $300 \mu \mathrm{L}$ into a sterile $5 \mathrm{~mL}$ syringe attached to a 0.22 $\mu \mathrm{m}$ pore size sterile filter (Millex ${ }^{\circledR}$-GV4, $4 \mathrm{~mm}$ filter units, $0.1 \mathrm{~cm}^{2}$ filtration area), filtered into a falcon tube $(12 \mathrm{~mm} \times$ $75 \mathrm{~mm}$, sterile, DNA free), and along with the sample stained with SYTOX-green to a final concentration of 0.05 $\mu \mathrm{M}$. The samples are then incubated with the stain for 20 min in the dark at room temperature. The samples can be kept at $4^{\circ} \mathrm{C}$ under these conditions for a period no longer than $20 \mathrm{~h}$ before being analyzed by the FCM; after that period, cell counts decrease (data not shown). All samples are then analyzed by FCM using a flow rate of $50 \mu \mathrm{L} \mathrm{min}^{-1}$

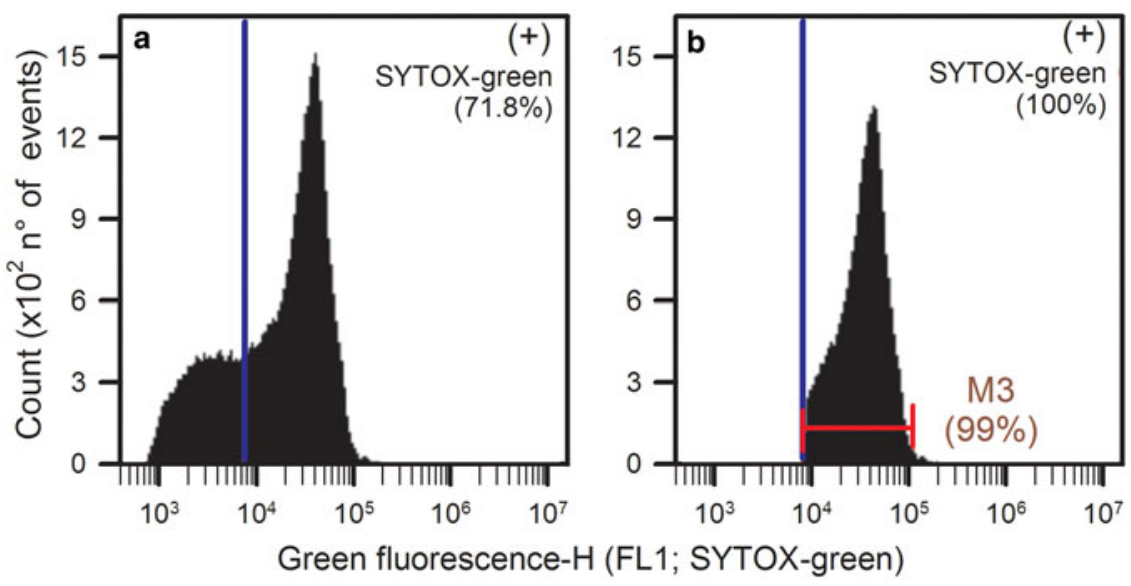

Fig. 9. Histogram-plots of a WD ice-core samples stained with SYTOX-green and showing gate 3 (M3). M3 corresponds to the red horizontal marker in (b). (a) All events on the stained samples (no gating applied). (b) Gated histogram-plot (P1 events included and P2 events excluded); M3 is defined in the gated histogram-plot to discriminate between the bacterial cluster and cellular debris and/or eukaryotic cells. 


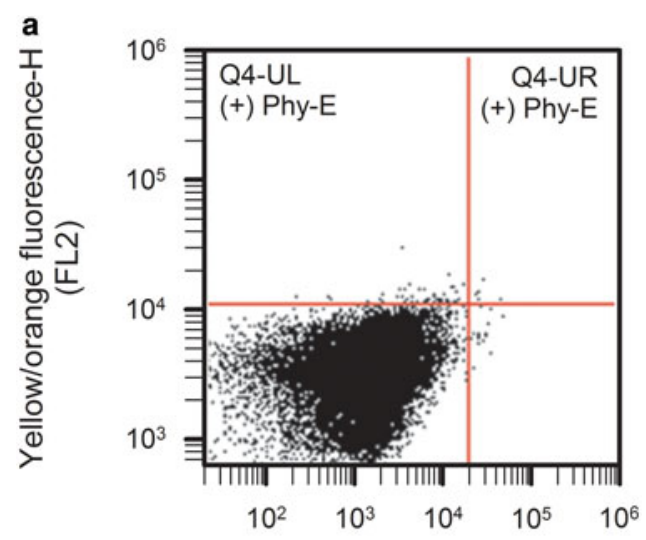

b
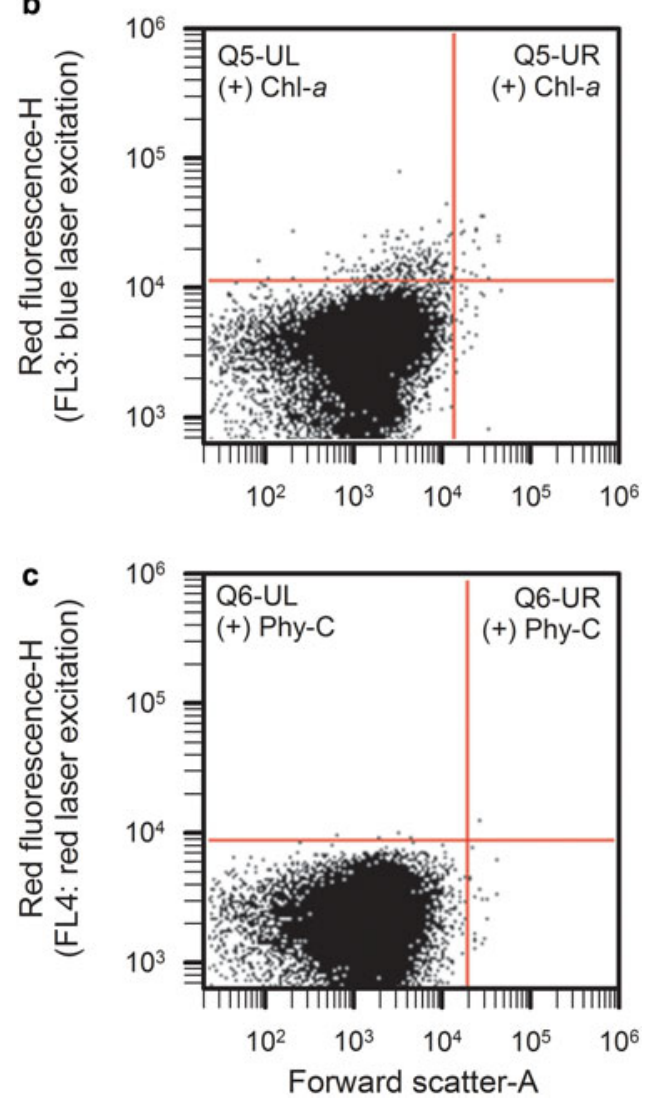

Fig. 10. Cytograms of a WD ice-core sample stained with SYTOXgreen and showing gates 4, 5 and $6(\mathrm{Q} 4, \mathrm{Q} 5, \mathrm{Q} 6)$. The three cytograms are gated by M3 (see Fig. 9). (a) Detection of Phy-E positive events by quadrant 4 (Q4; upper-left: UL, upper-right: UR). (b) Detection of Chl-a positive events by quadrant 5 (Q5; upper-left: UL, upper-right: UR). (c) Detection of Phy-C positive events by quadrant 6 (Q6; upper-left: UL, upper-right: UR).

with a core size of $12 \mu \mathrm{m}$. We analyzed around 30 samples $\mathrm{d}^{-1}$ based on each sample reaching 25000 events on gate $\mathrm{P} 1$, or until $1600 \mu \mathrm{L}$ had been analyzed by FCM, which corresponds at $32 \mathrm{~min}$. The samples and controls are analyzed in the following order: $250 \mu \mathrm{L}$ of blank control, $200 \mu \mathrm{L}$ for all samples as negative controls (unstained), $\sim 7$ background controls of $200 \mu \mathrm{L}$ (stained $0.2 \mu \mathrm{m}$ filtered samples), all of which allowed creation of gate 1 (P1). The stained samples are analyzed in random order. To clean the Sample Introduction Probe and prevent a reported slight carry-over between samples (Van Nevel and others, 2013), two backflushes are performed and Milli-Q water is run for $1 \mathrm{~min}$ between stained samples. Gating strategy is applied after data acquisition is performed.

\subsection{Application to WD ice-core samples}

To test our FCM protocol, 189 discrete samples of WD ice core were analyzed from 2100 to $2480 \mathrm{~m}$ (Fig. 12). That depth range was chosen because we had more sample volume available in this region of the core $(4.5-8 \mathrm{~mL}$ sample $\mathrm{e}^{-1}$ ), relative to other depths. This volume allowed us to directly observe and count prokaryotic cells by EFM while counting the same samples with FCM. The FCM analysis revealed a mean prokaryotic density of $6.10 \times 10^{4}$ cells $\mathrm{mL}^{-1}$ (range $6.53 \times 10^{3}-2.89 \times 10^{5}$ cells $\mathrm{mL}^{-1}$ ). In addition, the parallel sticks of ice from the same WD ice core were analyzed to test the reproducibility and cleanliness of the melter system (Fig. 12). The replicated samples show the same temporal trends and typically fall within the $95 \%$ $\mathrm{Cl}$ for the means belt of a generalized additive model (GAM) fitted to the data (Wood, 2006). Variation in the replicated ice sticks can result from spatial variability in prokaryotic density in the core and possible carry over from previous ice core samples as it is not possible to wash the melter system between each discrete sample.

\section{DISCUSSION}

We developed a protocol for the accurate and precise density measurement of non-photosynthetic prokaryotes archived in the WD ice core. This method is time efficient relative to direct microscopic determination of cell density. Results obtained from the WD ice core using this protocol revealed a unique long-term prokaryotic record that can be used to evaluate non-photosynthetic prokaryotic responses to climatic and environmental conditions.

Mechanical cutting of discrete samples, followed by slow melting at $4^{\circ} \mathrm{C}$ and ensuing decontamination procedures for microbiological, molecular-based and biogeochemical studies, have significantly increased our knowledge about prokaryotes in glaciers (Sheridan and others, 2003; Miteva and others, 2004; Christner and others, 2005; Priscu and others, 2007; Segawa and others, 2010). However, this traditional melting method is impractical for accessing a prokaryotic record of thousands of years and at high resolution because: (1) sample preparation is laborious, taking $\sim 2 \mathrm{~d}$ to clean and processes a section of ice core $(\sim 30 \mathrm{~cm}$ length); (2) large amounts of sample volume are required to ensure the ice used for analysis is clean; (3) the large sample volume requirement yields samples with low time resolution. In contrast, we used the ice-core melting system, which had for WD ice core a melting rate of $\sim 4 \mathrm{~cm} \mathrm{~min}^{-1}$ and an average warming rate of $\sim 80{ }^{\circ} \mathrm{C} \mathrm{min}^{-1}$, which is faster than the traditional slow mechanical melting method mentioned above $\left(\sim 0.03{ }^{\circ} \mathrm{C} \mathrm{min}^{-1}\right)$. It has been demonstrated that slow warming rates $\left(<0.5{ }^{\circ} \mathrm{C} \mathrm{min}{ }^{-1}\right)$ are more harmful for prokaryotic and eukaryotic cells than rapid rates (Mazur, 1966; Mazur and Schmidt, 1968; Calcott and MacLeod, 1974, 1975; Calcott and others, 1976; Parker and Martel, 2002; Walker and others, 2006). The faster warming/ melting rates of the continuous melting system are important for preserving prokaryotic cells and can reduce, or even prevent the recrystallization of intracellular ice, in effect preventing cell damage and lysis (Mazur, 1977; Parker and Martel, 2002; Walker and others, 2006).

Most previous estimates of non-photosynthetic prokaryotic density in melted ice-core samples relied upon filtration and epifluorescence analysis of stained cells, which are 


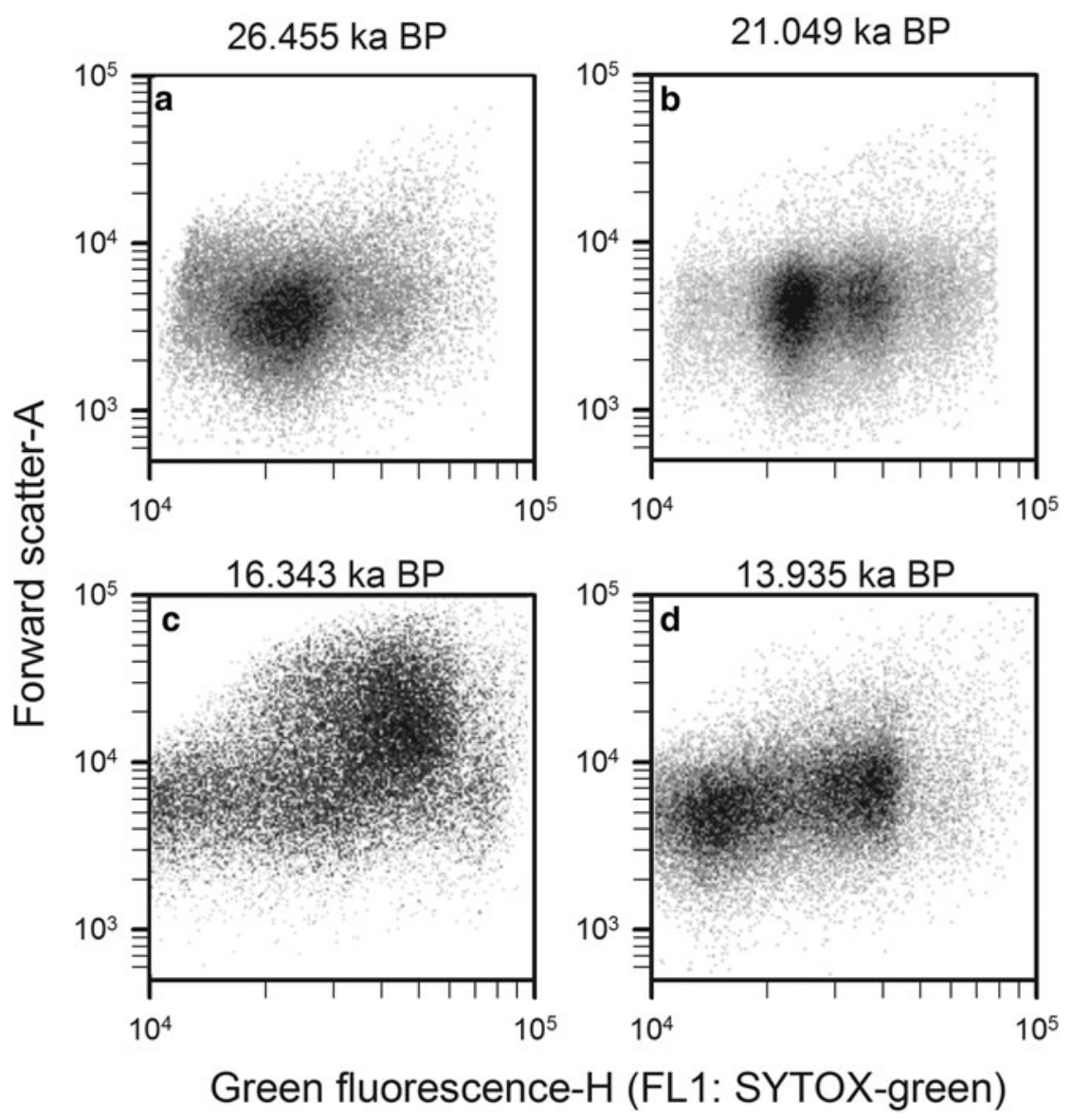

Fig. 11. Cytograms of four WD ice-core samples, stained with SYTOX-green showing final gating with the total prokaryotic cells and subgroups. Those plots include events on M3 and exclude events on Q4, Q5 and Q6. Sample mid-age is on top of each panel.

time consuming, can lead to microbial contamination and are plagued by low precision. Analysis via flow cytometer in a clean room allows relatively rapid processing of the samples within a closed fluidic system, eliminating much of the potential for contamination (Gasol and del Giorgio, 2000; Vives-Rego and others, 2000; Wang and others, 2010; Van Nevel and others, 2013). Sample preparation is rapid (few minutes), and a representative number of cells can be measured in a short time, which allows for the reduction of the baseline variation. The 'practical minimum detection limit' in our method is $10^{2}$ cells $\mathrm{mL}^{-1}$. We deem this a practical detection limit because we did not have sample volumes $>8 \mathrm{~mL}$ that allowed for higher absolute counts at lower cell densities $\left(<10^{2}\right.$ cells $\left.\mathrm{mL}^{-1}\right)$. The detection limit by FCM depends on the absolute number of cells counted and sample volume available since counts follow a Poisson distribution, which becomes more regular as the expected number of counts increases (Shapiro, 2003;

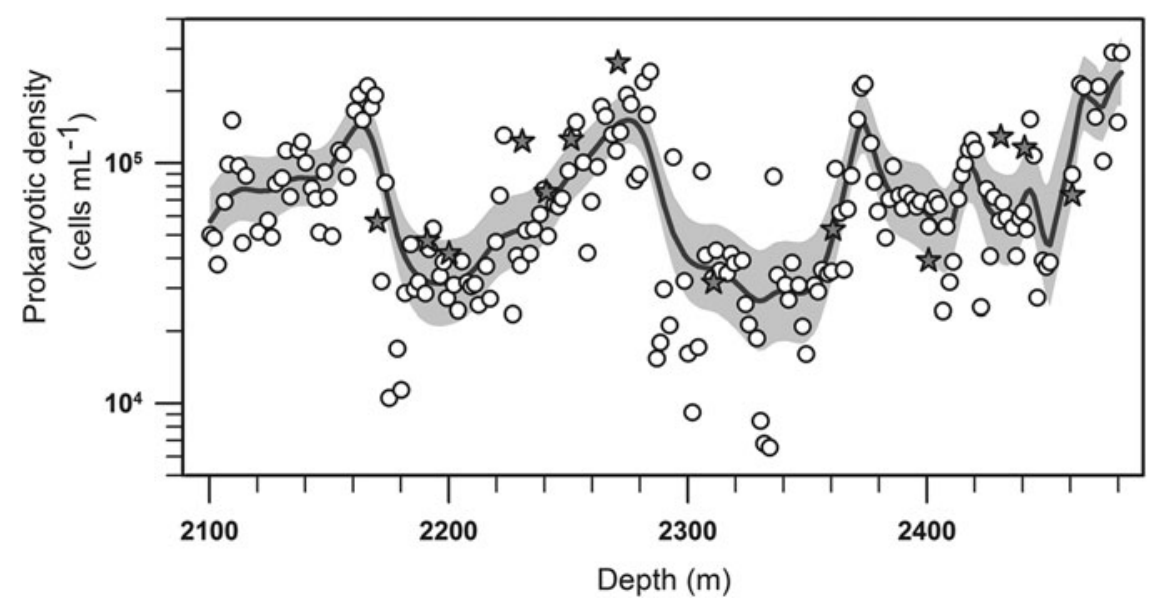

Fig. 12. Depth record of prokaryote density in the WD ice core using the FCM methods described in this paper. The solid black curve is the fitted model from the optimal quasi-Poisson GAM; the gray areas correspond to the $95 \%$ confidence band for means and the white dots are the observed prokaryotic density. Gray stars are parallel replicated ice samples that were melted days and months after the original ice sections by the ice-core melter system. Note the $y$-axis is on logarithmic scale. 
Bolker, 2008). For lower prokaryotic densities $\left(<10^{2}\right.$ cells $\mathrm{mL}^{-1}$ ), sample volumes $>8 \mathrm{~mL}$ are needed to obtain accurate and precise counts. In addition, the mean of the CV was $3.34 \%$ (range, $0.48-6.2 \%$ ), which agrees with the estimated precision for FCM by other studies (Gasol and del Giorgio, 2000; Nebe-von-Caron and others, 2000; Wang and others, 2010). In this study, accuracy was demonstrated by serial dilutions of WD samples; the log/log linear relation between observed and expected cell concentrations does not show a deviation from linearity $\left(r^{2}=0.995, p\right.$-value $<0.01$; Fig. 10b), and $95 \% \mathrm{Cl}$ for both intercept and slope are narrow and contain the values for the $1: 1 \mathrm{log} / \mathrm{log}$ linear relationship. Cleanliness of the instrument can be easily achieved (Fig. 2; Section 3.1), and a set of FCM controls allows reliability on the positive-target events (Figs 1, 2). Van Nevel and others (2013) utilized the same FCM instrument and showed that Milli-Q washes between samples are not necessary when dealing with similar cell concentrations (in the same order of magnitude); because the carryover accounts for only $0.53 \% \mathrm{CV}$ of the concentration of the latter sample. We did, however, keep the washing and back-flushing steps to prevent carryover because measurements were performed in random order, and sample cell densities were unknown.

A major challenge of employing FCM to counting prokaryotic cells in natural samples is to find a DNA stain that shows a broad spectral differentiation from autofluorescent particles and minimum non-specific binding (Vives-Rego and others, 2000). Dust concentrations have been shown to be higher at the LGM than during the Holocene by a factor of $\sim 80$ and $\sim 15$ in Greenland and Antarctic ice cores, respectively (Fischer and others, 2007). The European Project for Ice Coring in Antarctica (EPICA) showed a dust concentration record for the LGM with a mean of $1.95 \times 10^{5}$ particles $\mathrm{mL}^{-1}$ at a sampling frequency of 230 a (Delmonte and others, 2002). Our results show that SYTOX-green allows spectral differentiation between autofluorescent and DNA stained particles without non-specific binding to abiotic sediments (Fig. 3a), a result that corroborates results of Wobus and others (2003) and Klauth and others (2004).

Although SYTOX-green requires a compromised membrane to enter the cell (Lebaron and others, 1998a, b; Suller and Lloyd, 1999; Klauth and others, 2004), our cell counts obtained with both the EFM and FCM indicate that the cellular membranes in the melted WD samples were already membrane-compromised. The observed $\sim 2$-fold reduction of permeabilized prokaryotic cells after fixation (Fig. 4) may result from cell membrane changes caused by formalin (Hopwood, 1969; Meadows, 1971; Puchtler and Meloan, 1985; Kiernan, 2000). Melted glacial samples must be preserved to prevent degradation and/or cell growth. We conclude that a reduction in cell density by a factor of $\sim 2$ caused by formalin addition is insignificant when our reported prokaryotic density fluctuates between two orders of magnitude $\left(6.53 \times 10^{3}-2.89 \times 10^{5}\right.$; Fig. 12).

Compromised membranes can result from lack of source cell integrity, damage during atmospheric transport, and extended exposure to subzero temperatures or during the freeze-thaw processes. Although we do not know the status of the source cells in time, it is known that extensive periods of exposure to subzero temperatures can have a direct effect on membrane lipid conformation and hence, loss of membrane integrity of prokaryotic cells (Mazur and
Schmidt, 1968; Calcott and MacLeod, 1975; Mackey, 1984; D'Amico and others, 2006). Prolonged freezing had affected our samples because they were encased in ice from 27000 to 9600 a before 1950 CE. Undoubtedly, some prokaryotes can remain viable for as long as hundreds of thousands to millions of years when trapped in glacial ice (Christner and others, 2000, 2003; Sheridan and others, 2003; Bidle and others, 2007). Our samples were also exposed to at least one freeze-thaw processes. Calcott and MacLeod (1974, 1975) and Walker and others (2006) showed that freezing and thawing can produce compromised membranes during slow warming and that microorganisms vary greatly in their susceptibility or resistance to the lethal effects of freezing and thawing.

FCM flow rate is a critical parameter impacting the time required to measure samples and the cell detection and/or background noise (Gasol and del Giorgio, 2000; Shapiro, 2003). Our cell density comparison at different flow rates showed negligible variations over the flow rates tested. In contrast, background noise decreased with higher flow rates; we showed significant background variations between the lowest flow rate $\left(14 \mu \mathrm{L} \mathrm{min}^{-1}\right)$ and the other two flow rates tested ( 32 and $50 \mu \mathrm{L} \mathrm{min}^{-1}$ ). Van Nevel and others (2013) used the same FCM instrument and showed negligible variations in cell densities between three flow rates $\left(14,35,66 \mu \mathrm{L} \mathrm{min}^{-1}\right)$, choosing $66 \mu \mathrm{L} \mathrm{min}^{-1}$ to measure prokaryotic densities. We did not test a flow rate

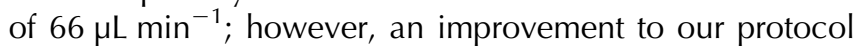
could be to increase the flow rate to $66 \mu \mathrm{L} \mathrm{min}{ }^{-1}$, which will decrease the time per run by a factor of 1.3.

Most studies of water-insoluble impurities in ice cores have reported only their water-insoluble 'dust' component (e.g. Ruth, 2003; Fischer and others, 2007; Lambert and others, 2008). Our results suggest that prokaryotic cells may also contribute to the water-insoluble impurities, indicating biotic and abiotic particles are preserved in the ice. Hara and Zhang (2012) showed that total airborne prokaryotic cell concentrations in Asian dust range from $10^{6}$ and $10^{7}$ cells $\mathrm{m}^{-3}$ and were correlated with the concentration of aerosol particles $>1 \mu \mathrm{m}$. These results, as well as those of others (e.g., Kellogg and Griffin, 2006; Pratt and others, 2009), indicate that bacterial particles can be an important component of atmospheric insoluble particles that can contribute to the ice-core record. Coulter counters or laser particle devices have been used frequently to quantify dust (abiotic particles) in ice cores but they cannot be used with efficacy to quantify prokaryotic cells in large part because cells are substantially smaller than most continental dust particles and often outside the size range of the measurement devices. Because the mass mode of continental dust found in ice cores is in the range, $3-5 \mu \mathrm{m}$, very small particles $(<1 \mu \mathrm{m})$ are generally not the focus of most insoluble dust studies.

Data from Coulter counters are based on the detection of electric signals generated by solid particles that are forced to flow through a small aperture tube in a conductive fluid ( $\mathrm{NaCl}$ solution). The passage of a cell through the aperture tube results in an increase in resistance by the displacement of its own volume of electrolyte from that region (Kubitschek and Friske, 1986). The sensitivity of this instrument depends on the orifice diameter and electrode size (Harris and Kell, 1985; Sun and Morgan, 2010). Under controlled laboratory conditions, Coulter counters with smaller aperture tubes $(20-30 \mu \mathrm{m})$ have been used successfully to quantify bacteria 
from pure cell cultures (Zimmermann and others, 1974; Kjelleberg and others, 1982; Henningson and others, 1997). For insoluble particle measurements on ice cores, the common aperture diameter is $50 \mu \mathrm{m}$ (e.g., Ruth and others, 2002; Delmonte and others, 2004; Lambert and others, 2008; Vallelonga and others, 2010), however, 30 $\mu \mathrm{m}$ (Biscaye and others, 1997) and $20 \mu \mathrm{m}$ (Steffensen, 1997) have also been reported. Coulter counters cannot be used to quantify prokaryotes in environmental samples for other reasons. For solid particles, the conductivity is constant under different experimental conditions, whereas the electrical properties of microorganisms change with the magnitude of the applied field, and dielectric breakdown of the membrane has been observed (Zimmermann and others, 1974, 1980; Harris and Kell, 1985). In addition, the saline solution $(\mathrm{NaCl})$ added to the samples can lead to shrinkage of cells due to osmotic stress, leaving the cells undetected (Csonka, 1989). Consequently, insoluble particles detected by Coulter counters may exclude most of the prokaryotic cells in the sample.

In contrast to Coulter counters, laser particle devices are based on light attenuation and scattering (Ruth, 2002, 2003; Ruth and others, 2002). The sample water is pumped through the detection cell where it is illuminated by a diode laser $(670$ or $680 \mathrm{~nm}$ ) with a power of 3 or $7 \mathrm{~mW}$. The size detection limit for laser particle devices is $\sim 1.0$ $\mu \mathrm{m}$ of the spherical equivalent particle diameter (Ruth and others, 2002), indicating that the coulter counter can detect a fraction of the prokaryotic size ranges $(0.2-3 \mu \mathrm{m})$. The detection of prokaryotic cell scattering however, is not easy; it depends upon various factors and requires specialized detectors and light sources. Prokaryotes scatter less light due to their small sizes. This is physically explained by the fact that the scattered light intensity increases as the sixth power of the particle's radius (Salzman, 1999). FCM that are able to detect prokaryotic cells only by scattering are equipped with powerful light sources $(\sim 100 \mathrm{~mW})$ of short wavelength because the light scattering detection increases by the square root of the light intensity (Steen, 2000), and the scatter intensity decreases as the fourth power of the wavelength (i.e. shorter wavelengths scatter light more strongly) (Salzman, 1999). Thus, to be able to detect prokaryotic cells only by scattering, instruments should have: (1) a powerful laser (>100 mW), (2) a sensitive detector (PTM or avalanche-photodiode instead of a photodiode), (3) light sources of short wavelengths (<600 nm) and (4) low background (Salzman, 1999; Steen, 2000). Relative to a laser particle counter, the PhytoCyt FCM has (1) a more powerful light source to measure particle's scattering (20 mW versus 3 or 7 $\mathrm{mW}$ for a laser counter), (2) a light source with a shorter wavelength (488 nm versus $670 \mathrm{~nm}$ for a laser counter), (3) the same scatter detector (both used photodiodes), and (4) a much lower flow rate $\left(50 \mu \mathrm{L} \mathrm{min}^{-1}\right.$ versus $20000 \mu \mathrm{L}$ $\min ^{-1}$ for a laser counter). Despite these differences, our FCM cannot detect prokaryotic cells by scattering alone; prokaryotic scatter typically falls within the equipment noise. Our protocol can discriminate prokaryotic cells based on excitation and emission of a high quantum yield fluorescent DNA stain (SYTOX-green) detected by a PTM tube, which can detect individual photons at low-light levels (weak signals) (Steen, 1986, 1992, 2000; Hadfield, 2009). In contrast, photodiode detectors gather average light and detect high-light levels (strong signals) (Wood, 1997, 1998; Shapiro, 2004). In addition to detector types, particle scattering can be increased by reducing flow velocity; the slower the cells move through the focus the more scattered light they emit and can be detected (Steen, 2000). However, laser particle detectors have a higher flow rate than FCM $\left(50 \mu \mathrm{L} \mathrm{min}{ }^{-1}\right.$ versus $\left.20000 \mu \mathrm{L} \mathrm{min}^{-1}\right)$. Consequently, insoluble particles detected by laser particle devices correspond primarily to dust particles whereas FCM can detect accurately fluorescently stained prokaryotic cells.

To evaluate our FCM protocol, we measured prokaryotic density in a short section of WD ice core (Fig. 12). The prokaryotic density record showed changes of two orders of magnitude from 2100 to $2480 \mathrm{~m}$. These depths correspond to Termination I, the period of most recent deglaciation (13 021-19386 a before $1950 \mathrm{CE})$, a climatic period with dramatic changes and the largest climatic oscillations of the past 20000 (Blanchon and Shaw, 1995; Mayewski and others, 1996; McManus and others, 2004). These preliminary results reveal that our method effectively detects prokaryotic cells and that their abundance in glacial ice responds to large-scale ecosystems and/or climatic processes.

\section{ACKNOWLEDGEMENTS}

This work was supported by US National Science Foundation (NSF) grants 0440943, 0839075 and 0839093. P. Santibáñez was funded by Chile Fulbright-CONICYT Scholarship. We thank J. D'Adrilli, O. Maselli, M. Sigl, D. Pasteris and others for assistance with ice-core melting and discrete sample collection, M. Skidmore for glacial sediments, C. Foreman and A. Michaud for bacterial isolates and T. Ranalli, T. Vick-Majors, M. Skidmore and A. Chiuchiolo for reading earlier versions of the manuscript. The authors appreciate the support of the WAIS Divide Science Coordination Office at the Desert Research Institute, Reno, NE, USA and University of New Hampshire, USA, for the collection and distribution of the WAIS Divide ice core and related tasks (NSF Grants 0230396, 0440817, 0944348; and 0944266). Kendrick Taylor led the field effort that collected the samples. The National Science Foundation Division of Polar Programs also funded the Ice Drilling Program Office (IDPO) and Ice Drilling Design and Operations (IDDO) group for coring activities; the National Ice Core Laboratory for curation of the core; the Antarctic Support Contractor for logistics support in Antarctica; and the 109th New York Air National Guard for airlift in Antarctica.

\section{REFERENCES}

Abyzov SS, Mitskevich IN and Poglazova MN (1998) Microflora of the deep glacier horizons of central Antarctica. Microbiology (Moscow), 67, 66-73

Banta JR, McConnell JR, Frey MM, Bales RC and Taylor K (2008) Spatial and temporal variability in snow accumulation at the West Antarctic Ice Sheet Divide over recent centuries. J. Geophys. Res., 113(D23), 1-8 (doi: 10.1029/2008JD010235)

Barrie L (1985) Atmospheric particles: their physical and chemical characteristics, and deposition processes relevant to the chemical composition of glaciers. Ann. Glaciol., 7, 100-108

Bidle KD, Lee S, Marchant DR and Falkowski PG (2007) Fossil genes and microbes in the oldest ice on earth. Proc. Natl. Acad. Sci. U. S. A., 104(33), 13455-13460 (doi: 10.1073/ pnas.0702196104) 
Biscaye PE and 6 others (1997) Asian provenance of glacial dust (stage 2) in the Greenland Ice Sheet Project 2 Ice Core, Summit, Greenland. J. Geophys. Res., 102(97), 26765 (doi: 10.1029/97JC01249)

Blanchon P and Shaw J (1995) Reef drowning during the last deglaciation-evidence for catastrophic sea level rise and ice-sheet collapse. Geology, 23(1), 4-8 (doi: 10.1130/0091-7613(1995) $023<0004:$ RDDTLD $>2.3$. CO;2)

Bojsen R, Torbensen R, Larsen CE, Folkesson A and Regenberg B (2013) The synthetic amphipathic peptidomimetic Itx109 is a potent fungicide that disturbs plasma membrane integrity in a sphingolipid dependent manner. PLOS ONE, 8(7) (doi: 10.1371/ journal.pone.0069483)

Bolker BM (2008) Ecological data and models in $R$, 1 st edn. Princeton University Press, Princeton, New Jersey, USA

Burnett SL and Beuchat LR (2002) Comparison of methods for fluorescent detection of viable, dead, and total Escherichia coli O157: $\mathrm{H} 7$ cells in suspensions and on apples using confocal scanning laser microscopy following treatment with sanitizers. Int. J. Food Microbiol., 74, 37-45 (doi: 10.1016/S0168-1605 (01)00714-0)

Burrows SM, Elbert W, Lawrence MG and Poschl U (2009a) Bacteria in the global atmosphere - part 1: review and synthesis of literature data for different ecosystems. Atmos. Chem. Phys., 9, 92639280 (doi: 10.5194/acp-9-9263-2009)

Burrows SM and 6 others (2009b) Bacteria in the global atmosphere - part 2: modelling of emissions and transport between different ecosystems. Atmos. Chem. Phys. Discuss., 9, 10829-10881 (doi: 10.5194/acp-9-9281-2009)

Calcott PH and MacLeod RA (1974) Survival of Escherichia coli from freeze-thaw damage: influence of nutritional status and growth rate. Can. J. Microbiol., 20, 683-689 (doi: 10.1139/m74-104)

Calcott PH and MacLeod RA (1975) The survival of Escherichia coli from freeze-thaw damage: the relative importance of wall and membrane damage. Can. J. Microbiol., 21, 1960-1968 (doi: 10.1139/m75-253)

Calcott PH, Lee SK and MacLeod RA (1976) The effect of cooling and warming rates on the survival of a variety of bacteria. Can. J. Microbiol., 22, 106-109 (doi: 106-109, 10.1139/m76015)

Castro HF, Classen AT, Austin EE, Norby RJ and Schadt CW (2010) Soil microbial community responses to multiple experimental climate change drivers. Appl. Environ. Microbiol., 76(4), 9991007 (doi: 10.1128/AEM.02874-09)

Christner BC and 5 others (2000) Recovery and identification of viable bacteria immured in glacial ice. Icarus, 144, 479-485 (doi: 10.1006/1999.6288)

Christner BC, Mosley-Thompson E, Thompson LG and Reeve JN (2003) Bacterial recovery from ancient glacial ice. Env. Microb., 5, 433-436 (doi: 10.1046/j.1462-2920.2003.00422.x)

Christner BC, Mikucki JA, Foreman CM, Denson J and Priscu JC (2005) Glacial ice cores: a model system for developing extraterrestrial decontamination protocols. Icarus, 174, 572-584 (doi: 10.1016/j.icarus.2004.10.027)

Christner BC and 9 others (2006) Limnological conditions in Subglacial Lake Vostok, Antarctica. Limnol. Oceanogr., 51(6), 2485-2501 (doi: 10.4319/lo.2006.51.6.2485)

Csonka LN (1989) Physiological and genetic responses of bacteria to osmotic stress. Microbiol. Rev., 53(1), 121-147

D'Amico S, Collins T, Marx J-C, Feller G and Gerday C (2006) Psychrophilic microorganisms: challenges for life. EMBO Rep., 7(4), 385-389 (doi: 10.1038/sj.embor.7400662)

Dansgaard W and 10 others (1993) Evidence for general instability of past climate from a 250-kyr ice-core record. Nature, 364, 218-220 (doi: 10.1038/364218a0)

Davidson $\mathrm{Cl}$, Bergin MH and Kuhns HD (1996) The deposition of particles and gases to ice sheets. In Wolff EW and Bales RC eds. Chemical exchange between the atmosphere and polar snow, vol. 43. Springer-Verlag, Berlin, Heidelberg, NATO ASI Series, 275-306 (doi: 10.1007/978-3-642-61171-1_12) de Groot RS, Wilson MA and Boumans RM (2002) Typology for the classification, description and valuation of ecosystem functions, goods and services. Ecol. Econ., 41(3), 393-408 (doi: 10.1016/ S0921-8009(02)00089-7)

Delmonte B, Petit JR and Maggi V (2002) Glacial to Holocene implications of the new 27000-year dust record from the EPICA Dome C (East Antarctica) ice core. Clim. Dyn., 18(8), 647-660 (doi: 10.1007/s00382-001-0193-9)

Delmonte B and 5 others (2004) Dust size evidence for opposite regional atmospheric circulation changes over east Antarctica during the last climatic transition. Clim. Dyn., 23, 427-438 (doi: 10.1007/s00382-004-0450-9)

Dieser M, Greenwood M and Foreman CM (2010) Carotenoid pigmentation in antarctic heterotrophic bacteria as a strategy to withstand environmental stresses. Arct. Antarct. Alp. Res., 42 (4), 396-405 (doi: 10.1657/1938-4246-42.4.396)

Falkowski PG, Fenchel T and Delong EF (2008) The microbial engines that drive Earth's biogeochemical cycles. Science, $\mathbf{3 2 0}$ (5879), 1034-1039 (doi: 10.1126/science.1153213)

Field CB (1998) Primary production of the biosphere: integrating terrestrial and oceanic components. Science, 281(5374), 237-240 (doi: 10.1126/science.281.5374.237)

Finlay BJ, Maberly SC and Cooper JI (1997) Microbial diversity and ecosystem function. Oikos, 80, 209-213 (doi: 10.2307/3546587)

Fischer H, Siggaard-Andersen M, Ruth U, Röthlisberger R and Wolff E (2007) Glacial/Interglacial changes in mineral dust and sea-salt records in polar ice cores: sources, transport, and deposition. Rev. Geophys., 45(2005), 1-26 (doi: 10.1029/2005RG000192.1)

Gasol JM and del Giorgio PA (2000) Using flow cytometry for counting natural planktonic bacteria and understanding the structure of planktonic bacterial communities. Sci. Mar., 64(2), 197-224 (doi: 10.3989/scimar.2000.64n2197)

Gasol JM, Zweifel UL, Peters F, Fuhrman JA and Hagström ^̊ (1999) Significance of size and nucleic acid content heterogeneity as measured by flow cytometry in natural planktonic bacteria. Appl. Environ. Microbiol., 65(10), 4475

Gorham E, Brush GS, Graumlich LJ, Rosenzweig ML and Johnson AH (2001) The value of paleoecology as an aid to monitoring ecosystems and landscapes, chiefly with reference to North America. Environ. Rev., 9, 99-126 (doi: 10.1139/a01-003)

Griffin DW (2007) Atmospheric movement of microorganisms in clouds of desert dust and implications for human health. Clin. Microbiol. Rev., 20, 459-477 (doi: 10.1128/CMR.00039-06)

Griffin DW and 5 others (2003) Atmospheric microbiology in the northern Caribbean during African dust events. Aerobiologia, 19, 143-157 (doi: 10.1023/B:AERO.0000006530.32845.8d)

Hadfield RH (2009) Single-photon detectors for optical quantum information applications. Nat. Photonics, 3(12), 696-705 (doi: 10.1038/nphoton.2009.230)

Hara K and Zhang D (2012) Bacterial abundance and viability in long-range transported dust. Atm. Env., 47, 20-25 (doi: 10.1016/j.atmosenv.2011.11.050)

Harris CM and Kell DB (1985) The estimation of microbial biomass. Biosensors J., 1, 17-84 (doi: 10.1016/0265-928X(85)85005-7)

Henningson EW, Lundquist M, Larsson E, Sandström G and Forsman M (1997) A comparative study of different methods to determine the total number and the survival ratio of bacteria in aerobiological samples. J. Aerosol Sci., 28(3), 459-469 (doi: 10.1016/S0021-8502(96)00447-8)

Hopwood D (1969) Fixatives and fixation: a review. Histochem. J., 1, 323-360 (doi: 10.1007/BF01003278)

Jackson JBC and Erwin DH (2006) What can we learn about ecology and evolution from the fossil record? Trends Ecol. Evol., 21(6), 322-328 (doi: 10.1016/j.tree.2006.03.017)

Javaux EJ, Marshall CP and Bekker A (2010) Organic-walled microfossils in 3.2-billion-year-old shallow-marine siliciclastic deposits. Nature, 463(7283), 934-938 (doi: 10.1038/nature08793)

Jones LJ and Singer VL (2001) Fluorescence microplate-based assay for tumor necrosis factor activity using SYTOX green stain. Anal. Biochem., 293(1), 8-15 (doi: 10.1006/abio.2001.5116) 
Kasting JF and Siefert JL (2002) Life and the evolution of Earth's atmosphere. Science, 296(5570), 1066-1068 (doi: 10.1126/ science.1071184)

Kellogg CA and Griffin DW (2006) Aerobiology and the global transport of desert dust. Trends Ecol. Evol., 21, 638-644

Kiernan JA (2000) Formaldehyde, formalin, paraformaledhyde and glutaraldehyde: what they are and what they do. Micros. Today 00-1, 8-12

Kirchman DL (1993) Statistical analysis of direct counts of microbial abundance. In Kemp PF, Sherr BF, Sherr EB and Cole JJ eds. Handbook of methods in aquatic microbial ecology. Lewis Publishers, Florida, USA

Kirchman DL, Sigda J, Kapuscinski R and Mitchell R (1982) Statistical analysis of the direct count method for enumerating bacteria. Appl. Environ. Microbiol., 44(2), 376-382

Kjelleberg S, Humphrey BA and Marshall KC (1982) Effect of interfaces on small, starved marine bacteria. Appl. Environ. Microbiol., 43(5), 1166-1172

Klauth P, Wilhelm R, Klumpp E, Poschen L and Groeneweg J (2004) Enumeration of soil bacteria with the green fluorescent nucleic acid dye SYTOX green in the presence of soil particles. J Microbiol. Methods, 59(2), 189-198 (doi: 10.1016/j. mimet.2004.07.004)

Kopp RE, Kirschvink JL, Hilburn IA and Nash CZ (2005) The Paleoproterozoic snowball Earth: a climate disaster triggered by the evolution of oxygenic photosynthesis. Proc. Natl. Acad. Sci. U. S. A., 102(32), 11131-6 (doi: 10.1073/pnas.0504878102)

Kubitschek HE and Friske JA (1986) Determination of bacterial cell volume with the Coulter Counter. J. Bacteriol., 168(3), 14661467

Kump LR (2008) The rise of atmospheric oxygen. Nature, 451(7176), 277-278 (doi: 10.1038/nature06587)

Lambert $\mathrm{F}$ and 9 others (2008) Dust-climate couplings over the past 800,000 years from the EPICA Dome C ice core. Nature, 452 (7187), 616-619 (doi: 10.1038/nature06763)

Lebaron P, Catala P, Parthuisot N and Oce O (1998a) Effectiveness of SYTOX green stain for bacterial viability assessment. Appl. Environ. Microbiol., 64(7), 2697

Lebaron P, Parthuisot N, Catala P and Oce O (1998b) Comparison of blue nucleic acid dyes for flow cytometric enumeration of bacteria in aquatic systems. Appl. Environ. Microbiol., 64(5), 1725

Lebaron P and 5 others (2001) Does the high nucleic acid content of individual bacterial cells allow us to discriminate between active cells and inactive cells in aquatic systems? Appl. Environ. Microbiol., 67(4), 1775 (doi: 10.1128/AEM.67.4.1775)

Lebaron P and 5 others (2002) Variations of bacterial-specific activity with cell size and nucleic acid content assessed by flow cytometry. Aquat. Microb. Ecol., 28, 131-140 (doi: 10.3354/ ame028131)

Lee JA and 33 others (2008) MIFlowCyt: the minimum information about a flow cytometry experiment. Cytometry $A, 73(10), 926-$ 930 (doi: 10.1002/cyto.a.20623)

Li WKW, Jellett JF and Dickie PM (1995) DNA distributions in planktonic bacteria stained with TOTO or TO-PRO. Limnol. Oceanogr., 40(8), 1485-1495 (doi: 10.4319/lo.1995.40.8.1485)

Lüthi D and 10 others (2008) High-resolution carbon dioxide concentration record 650,000-800,000 years before present. Nature, 453(7193), 379-382 (doi: 10.1038/nature06949)

Mackey BM (1984) Lethal and sublethal effects of refrigeration freezing and freeze-drying on microoganisms. Soc. Appl. Bacteriol. Symp. Ser., 12, 45-75

Madsen EL (2011) Microorganisms and their roles in fundamental biogeochemical cycles. Curr. Opin. Biotechnol., 22(3), 456464 (doi: 10.1016/j.copbio.2011.01.008)

Marie D, Partensky F, Jacquet S and Vaulot D (1997) Enumeration and cell cycle analysis of natural populations of marine picoplankton by flow cytometry using the nucleic acid stain SYBR I. Appl. Environ. Microbiol., 63(1), 186-193

Marie D, Partensky F, Vaulot D and Brussaard CP (1999) Enumeration of phytoplankton, bacteria, and viruses in marine samples. Curr. Protoc. Cytom. Supplement 10, 11.11.111.11.15 (doi: 10.1002/0471142956.cy1111s10)

Mayewski PA and 13 others (1996) Climate change during the last deglaciation in Antarctica. Science, 272(5268), 1636-1638 (doi: 10.1126/science.272.5268.1636)

Mazur P (1966) Theoretical and experimental effects of cooling and warming velocity on the survival of frozen and thawed cells. Cryobiology, 2(1), 181-192 (doi: 10.1016/S0011-2240(66)80165-7)

Mazur P (1977) The role of intracellular freezing in the death of cells cooled at supraoptimal rates. Cryobiology, 14, 251-272 (doi: 10.1016/0011-2240(77)90175-4)

Mazur P and Schmidt JJ (1968) Interactions of cooling velocity, temperature, and warming velocity on the survival of frozen and thawed yeast. Cryobiology, 5, 1-17 (doi: 10.1016/S0011-2240 (68)80138-5)

McConnell JR, Lamorey GW, Lambert SW and Taylor KC (2002) Continuous ice-core chemical analyses using inductively coupled plasma mass spectrometry. Environ. Sci. Technol., 36 (775), 7-11 (doi: 10.1021/es011088z)

McManus JF, Francois R, Gherardi J-M, Keigwin LD and BrownLeger S (2004) Collapse and rapid resumption of Atlantic meridional circulation linked to deglacial climate changes. Nature, 428(6985), 834-837 (doi: 10.1038/nature02494)

Meadows PS (1971) The attachment of bacteria to solid surfaces. Arch. fr Mikrobiol., 75, 374-381 (doi: 10.1007/BF00407699)

Meyer O (1993) Functional groups of microorganisms. In Biodiversity and ecosystem function. Ecological Studies 99, Springer, Berlin, 67-96

Miteva VI, Sheridan PP and Brenchley JE (2004) Phylogenetic and physiological diversity of microorganisms isolated from a deep Greenland glacier ice core. Appl. Environ. Microbiol., 70(1) (doi: 10.1128/AEM.70.1.202-213.2004)

Miteva VI, Teacher C, Sowers T and Brenchley JE (2009) Comparison of the microbial diversity at different depths of the GISP2 Greenland ice core in relationship to deposition climates. Environ. Microbiol., 11(3), 640-656 (doi: 10.1111/j.14622920.2008.01835.x)

Morono Y, Terada T, Kallmeyer J and Inagaki F (2013) An improved cell separation technique for marine subsurface sediments: applications for high-throughput analysis using flow cytometry and cell sorting. Environ. Microbiol., 15(10), 2841-2849 (doi: 10.1111/1462-2920.12153)

Mortimer FC, Mason DJ and Gant VA (2000) Flow cytometric monitoring of antibiotic-induced injury in Escherichia coli using cellimpermeant fluorescent probes. Antimicrob. Agents Chemother., 44(3), 676-681 (doi: 10.1128/AAC.44.3.676-681.2000)

Müller S and Nebe-von-Caron G (2010) Functional single-cell analyses: flow cytometry and cell sorting of microbial populations and communities. FEMS Microbiol. Rev., 34(4), 554-587 (doi: 10.1111/j.1574-6976.2010.00214)

Müller S and Tárnok A (2008) Making cytometry publications comprehensive. Cytometry A., 73(10), 875-876 (doi: 10.1002/cyto. a.20650)

Nebe-von-Caron G (2009) Standardization in microbial cytometry. Cytometry A., 75(2), 86-89 (doi: 10.1002/cyto.a.20696)

Nebe-von-Caron G, Stephens PJ, Hewitt CJ, Powell JR and Badley RA (2000) Analysis of bacterial function by multi-colour fluorescence flow cytometry and single cell sorting. J. Microbiol. Methods, 42(1), 97-114 (doi: 10.1016/S0167-7012 (00)00181-0)

Noffke N, Eriksson KA, Hazen RM and Simpson EL (2006) A new window into early Archean life: microbial mats in Earth's oldest siliciclastic tidal deposits (3.2 Ga Moodies Group, South Africa). Geology, 34(4), 253 (doi: 10.1130/G22246.1)

Park J-Y, Kug J-S, Bader J, Rolph R and Kwon M (2015) Amplified Arctic warming by phytoplankton under greenhouse warming. Proc. Natl. Acad. Sci. U.S.A., 112(19), 5921-5926 (doi: 10.1073/pnas.1416884112)

Parker LV and Martel CJ (2002) Long-term survival of enteric microorganism in frozen wastewater inn technical report TR-02-16 of 
the U.S. Army Corps of Engineers, Engineer Research and Development Center, Cold Regions Research and Engineering Laboratory (ERDC/CRREL). U.S. Army Corps of Engineers, Hanover, NH

Perfumo A and Marchant R (2010) Global transport of thermophilic bacteria in atmospheric dust. Env. Microb. Rep., 2, 333-339 (doi: 10.1111/j.1758-2229.2010.00143.x)

Pratt KA and 8 others (2009) In situ detection of biological particles in cloud ice-crystals. Nat. Geosci., 2, 398-401 (doi: 10.1038/ ngeo521)

Priscu JC and Christner B (2004) Earth's icy biosphere. In Microbial diversity and bioprospecting. American Society for Microbiology, Washington, DC

Priscu JC and 11 others (1999) Geomicrobiology of subglacial ice above lake Vostok, Antarctica. Science, 286(5447), 2141-2144 (doi: 10.1126/science.286.5447.2141)

Priscu JC, Christner BC, Foreman CM and Royston-Bishop G (2007) Biological material in ice cores. In Encyclopedia of quaternary sciences, vol. 2, Elsevier, London, 1156-4466

Puchtler H and Meloan SN (1985) On the chemistry of formaldehyde fixation and its effects on immune histochemical reactions. Histochemistry, 82, 201-204 (doi: 10.1007/BF00501395)

$R$ Development Core Team (2012) $R$ : a language and environment for statistical computing. R Foundation for Statistical Computing, Vienna, Austria (http://www.R-project.org/)

Rasmussen B (2000) Filamentous microfossils in a 3,235-millionyear-old volcanogenic massive sulphide deposit. Nature, 405, 676-679 (doi: 10.1038/35015063)

Roth BL and 7 others (1997) Bacterial viability and antibiotic susceptibility testing with SYTOX green nucleic acid stain. Appl. Environ. Microbiol., 63(6), 2421-2431

Ruth U (2002) Concentration and size distribution of microparticles in the NGRIP ice core (Central Greenland) during the last glacial period. (PhD dissertation, Berichte zur Polar-und Meeresforsch, Bremen)

Ruth U (2003) Continuous record of microparticle concentration and size distribution in the central Greenland NGRIP ice core during the last glacial period. J. Geophys. Res., 108, 1-12 (doi: 10.1029/2002JD002376)

Ruth $U$ and 5 others (2002) High-resolution microparticle profiles at NorthGRIP, Greenland: case studies of the calcium-dust relationship. Ann. Glaciol., 35, 237-242 (doi: http://dx.doi.org/10.3189/ 172756402781817347)

Salzman GC (1999) Light scatter : detection and usage. Curr. Protoc. Cytom., 13, 1-8 (doi: 10.1002/0471142956.cy0113s09)

Schimel J (2001) Biogeochemical models: implicit vs. explicit microbiology. In Schulze ED and 6 others eds. Global biogeochemical cycles in the climate system. Academic Press, New York, 177-183

Segawa T, Ushida K, Narita H, Kanda H and Kohshima S (2010) Bacterial communities in two Antarctic ice cores analyzed by 16S rRNA gene sequencing analysis. Polar Sci., 4(2), 215-227 (doi: 10.1016/j.polar.2010.05.003)

Shapiro HM (2003) Practical flow cytometry, 4th edn. Wiley-Liss, New Jersey

Shapiro HM (2004) Lasers for flow cytometry in current protocols in cytometry. John Wiley and Sons, New York (doi: 10.1002/ 0471142956.cy0109s27)

Sheridan PP, Miteva VI and Brenchley JE (2003) Phylogenetic analysis of anaerobic psychrophilic enrichment cultures obtained from a Greenland glacier ice core. Appl. Environ. Microbiol., 69(4), 2153-2160 (doi: 10.1128/AEM.69.4.2153)

Singh BK, Bardgett RD, Smith P and Reay DS (2010) Microorganisms and climate change: terrestrial feedbacks and mitigation options. Nat. Rev. Microbiol., 8(11), 779-790 (doi: 10.1038/ nrmicro2439)

Singh BK and 12 others (2014) Loss of microbial diversity in soils is coincident with reductions in some specialized functions. Environ. Microbiol., 16, 2408-2420 (doi: 10.1111/1462-2920.12353)
Steen HB (1986) Simultaneous separate detection of low angle and large angle light scattering in an Arc Lamp-Based Flow Cytometer. Cytometry, 7, 445-449 (doi: 10.1002/cyto.990 070509)

Steen HB (1992) Noise, sensitivity, and resolution of flow cytometers. Cytometry, 13(8), 822-830 (doi: 10.1002/cyto.990 130804)

Steen HB (2000) Flow cytometry of bacteria: glimpses from the past with a view to the future. J. Microbiol. Methods, 42(1), 65-74 (doi: 10.1016/S0167-7012(00)00177-9)

Steffensen JP (1997) The size distribution of microparticles from selected segments of Greenland ice core project ice core representing different climatic periods. J. Geophys. Res., 102(97), 26,755-26,763 (doi: 10.1029/97JC01490)

Suller MT and Lloyd D (1999) Fluorescence monitoring of antibioticinduced bacterial damage using flow cytometry. Cytometry, 35 (3), 235-241

Sun T and Morgan H (2010) Single-cell microfluidic Impedance cytometry: a review. Microfluid. Nanofluidics, 8(4), 423-443 (doi: 10.1007/s10404-010-0580-9)

Vallelonga P and 12 others (2010) Lead isotopic compositions in the EPICA Dome C ice core and Southern Hemisphere potential source areas. Quat. Sci. Rev., 29(1-2), 247-255 (doi: 10.1016/ j.quascirev.2009.06.019)

Van Nevel S, Koetzsch S, Weilenmann $\mathrm{H}-\mathrm{U}$, Boon $\mathrm{N}$ and Hammes $\mathrm{F}$ (2013) Routine bacterial analysis with automated flow cytometry. J. Microbiol. Methods, 94(2), 73-76 (doi: 10.1016/j.mimet. 2013.05.007)

Vives-Rego J, Lebaron P and Nebe-von Caron G (2000) Current and future applications of flow cytometry in aquatic microbiology. FEMS Microbiol. Rev., 24(4), 429-448 (doi: http://www.ncbi nlm.nih.gov/pubmed/10978545)

Walker VK, Palmer GR and Voordouw G (2006) Freeze-thaw tolerance and clues to the winter survival of a soil community. Appl. Environ. Microbiol., 72(3), 1784-1792 (doi: 10.1128/AEM.72.3. 1784-1792.2006)

Wang Y, Hammes F, De Roy K, Verstraete W and Boon N (2010) Past, present and future applications of flow cytometry in aquatic microbiology. Trends Biotechnol., 28(8), 416-424 (doi: 10.1016/j.tibtech.2010.04.006)

White D (2007) Physiology and biochemistry of prokaryotes. University Press, Oxford, New York

Whitman WB, Coleman DC and Wiebe WJ (1998) Prokaryotes: the unseen majority. Proc. Natl. Acad. Sci. U. S. A., 95, 6578-6583 (doi: 10.1073/pnas.95.12.6578)

Willis KJ and Birks HJB (2006) What is natural? The need for a longterm perspective in biodiversity conservation. Science, 314, 1261-1265 (doi: 10.1126/science.1122667)

Willis KJ, Bailey RM, Bhagwat SA and Birks HJB (2010) Biodiversity baselines, thresholds and resilience: testing predictions and assumptions using palaeoecological data. Trends Ecol. Evol., 25, 583-591 (doi: 10.1016/j.tree.2010.07.006)

Wobus A and 6 others (2003) Microbial diversity and functional characterization of sediments from reservoirs of different trophic state. FEMS Microbiol. Ecol., 46(3), 331-347 (doi: 10.1016/S0168-6496(03)00249-6)

Wolff EW and 29 others (2010) Changes in environment over the last 800,000 years from chemical analysis of the EPICA Dome C ice core. Quat. Sci. Rev., 29(1-2), 285-295 (doi: 10.1016/j.quascirev. 2009.06.013)

Wood JC (1997) Establishing and maintaining system linearity. In Current protocols in cytometry. John Wiley and Sons, New York (doi: 10.1002/0471142956.cy0104s47)

Wood JC (1998) Fundamental flow cytometer properties governing sensitivity and resolution. Cytometry, 33, 260-266 (doi: 10.1002/(SICI)1097-0320(19981001)33:2<260::AID-CYTO23> 3.0.CO;2-R)

Wood SN (2006) Generalized additive models: an introduction with $R$. CRC Press, Boca Raton 
Xiang SR, Shang TC, Chen Y and Yao TD (2009) Deposition and postdeposition mechanisms as possible drivers of microbial population variability in glacier ice: minireview. FEMS Microbiol. Ecol., 70, 165-176 (doi: 10.1111/j.1574-6941.2009.00759.x)

Yergeau E and 6 others (2012) Shifts in soil microorganisms in response to warming are consistent across a range of Antarctic environments. ISME J., 6(3), 692-702 (doi: 10.1038/ ismej.2011.124)
Zimmermann U, Pilwat G and Riemann F (1974) Dielectric breakdown of cell membranes. Biophys. J., 14, 881-899 (doi: 10.1016/S0006-3495(74)85956-4)

Zimmermann U, Groves M, Schnabl H and Pilwat G (1980) Development of a new coulter counter system: measurement of the volume, internal conductivity, and dielectric breakdown voltage of a single guard cell protoplast of Vicia faba. J. Membr. Biol., 52(1), 37-50 (doi: 10.1007/BF01869004)

MS received 28 July 2015 and accepted in revised form 27 February 2016; first published online 2 May 2016 